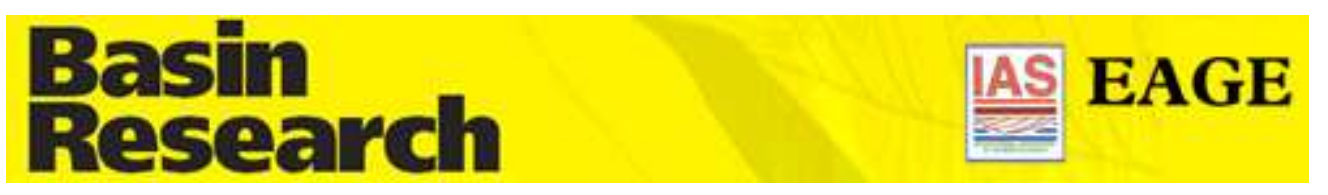

\title{
STRUCTURE AND RECENT EVOLUTION OF THE HAZAR BASIN. A STRIKE-SLIP BASIN ON THE EAST ANATOLIAN FAULT, EASTERN TURKEY.
}

\begin{tabular}{|r|l|}
\hline Journal: & Basin Research \\
\hline Manuscript ID: & BRE-053-2009.R3 \\
\hline Manuscript Type: & Original Article \\
\hline Author: & \\
\hline Complete List of Authors: & $\begin{array}{l}\text { Garcia Moreno, David; Royal Observatory of Belgium, Seismology } \\
\text { Section; Ghent University, Renard Centre of Marine Geology } \\
\text { Hubert-Ferrari, Aurelia; Royal Observatory of Belgium, Seismology } \\
\text { Section; Ecole Normale Supérieure, Laboratoire de géologie } \\
\text { Moernaut, Jasper; Ghent University, Renard Centre of Marine } \\
\text { Geology } \\
\text { Fraser, Jeffrey; Royal Observatory of Belgium, Seismology Section } \\
\text { Boes, Xavier; Royal Observatory of Belgium, Seismology Section } \\
\text { Van Daele, Maarten; Ghent University, Renard Centre of Marine } \\
\text { Geology } \\
\text { Avsar, Ulas; Royal Observatory of Belgium, Seismology Section; } \\
\text { Ghent University, Renard Centre of Marine Geology } \\
\text { Çağatay, Namik; Istanbul Technical University, Eastern } \\
\text { Mediterranean Centre for Oceanography and Limnology } \\
\text { De Batist, Marc; Ghent University, Renard Centre of Marine Geology }\end{array}$ \\
\hline Keywords: & \begin{tabular}{l} 
strike-slip basins, structure, tectonics and sedimentation \\
\hline
\end{tabular} \\
\hline
\end{tabular}

\section{今 scholaroNE"


STRUCTURE AND RECENT EVOLUTION OF THE HAZAR BASIN. A STRIKE-SLIP

\title{
BASIN ON THE EAST ANATOLIAN FAULT, EASTERN TURKEY.
}

\author{
D. Garcia Moreno 1, 2, A. Hubert-Ferrari 1, 3, J. Moernaut 2, J. G. Fraser 1, X. Boes 1, M. Van Daele 2, U. \\ Avsar 1, 2, N. Çağatay 4 \& M. De Batist 2
}

\begin{abstract}
1: Royal Observatory of Belgium, Section of Seismology. 3 Av. Circulaire, 1180 Brussels. Belgium.
2: Renard Centre of Marine Geology, Ghent University. 281 Krijgslaan (S. 8), B-9000, Ghent. Belgium.

3: Ecole Normale Supérieure, Laboratoire de géologie UMR 8538, 24 rue Lhomond, 75231 Paris CEDEX 5.

4: Eastern Mediterranean Centre for Oceanography and Limnology, Istanbul Technical University, Faculty of

Mining, Maslak 34469, Istanbul.
\end{abstract}

Correspondence: David Garcia Moreno, Royal Observatory of Belgium, Section of Seismology. 3 Av. Circulaire, 1180, Brussels, Belgium. E-mail: David.GarciaMoreno@oma.be

\begin{abstract}
The Hazar Basin is a $25 \mathrm{~km}$ long, $7 \mathrm{~km}$ wide and $216 \mathrm{~m}$ deep depression located on the central section of the East Anatolian Fault zone (eastern Turkey) and predominantly overlain by Lake Hazar. This basin has previously been described as a pull-apart basin because of its rhombic shape and an apparent fault step-over between the main fault traces situated at the southwestern and northeastern ends of the lake. However, detailed structural investigation beneath Lake Hazar has not previously been undertaken to verify this interpretation.
\end{abstract}

Geophysical and sedimentological data from Lake Hazar were collected during field campaigns in 2006 and 2007. The analysis of this data reveals that the main strand of the East Anatolian Fault (the Master Fault) is continuous across the Hazar Basin, connecting the two segments previously assumed to be the sidewall faults of a pull-apart structure. In the northeastern part of the lake, an asymmetrical subsiding sub-basin, bounded by two major faults, is cross-cut by the Master Fault, which forms a releasing bend within the lake. Comparison of the 
structure revealed by this study with analogue models produced for transtensional step-overs suggests that the Hazar Basin structure represents a highly evolved pull-apart basin, to the extent that the previous asperity has been bypassed by a linking fault. The absence of a step-over structure at the Hazar Basin means that no significant segmentation boundary is recognised on the East Anatolian Fault between Palu and Sincik. Therefore, this fault segment is capable of causing larger earthquakes than previously recognised.

\section{Introduction}

Strike-slip faults form some of the most continuous and linear fault systems on earth. However, these fault systems usually comprise complex zones consisting of en echelon fault and fold segments (Wilcox et al., 1973; Cunningham \& Mann, 2007). Hence, discontinuities existing at different scales along strike are common and can provide valuable information concerning the evolution of fault geometry (Cunningham \& Mann, 2007). These discontinuities comprise abrupt changes of the fault strike angle ("fault bends") or discrete lateral steps in the fault trace ("stepovers") (Mann et al., 1983, 1995; Cunningham \& Mann, 2007). Depending on fault geometry and the local stress field, these discontinuities will be the locus of compression (transpressional zones) or extension (transtensional zones) leading to the formation of a positive relief or a basin respectively (Sylvester, 1988; Cunningham \& Mann, 2007). Discontinuities of significant scale can behave as fault segmentation boundaries, where individual fault ruptures terminate (Barka \& Kadinsky-Cade, 1988; Lettis et al., 2002). Therefore, the presence of large fault bends or/and step-overs on a strike-slip fault system will strongly influence the length of fault ruptures, which is proportional to earthquake magnitude (Wells \& Coppersmith, 1994).

The structure and evolution of step-overs on strike-slip faults have been studied extensively in natural and experimental settings (e.g. Aydin \& Nur, 1982; Koçyiğit, 1989; Zhang et al., 1989; 
Dooley \& McClay, 1997; Rahe et al., 1998; Barnes et al., 2001; McClay \& Bonora, 2001; Wu et al., 2009). According to these studies, step-overs tend to be abandoned over time, most commonly because a new strike-slip fault develops diagonally across the step-over linking the original boundary fault segments (e.g. Zhang et al., 1989). Indeed, analogue models have shown that secondary fault splays grow across the step-over from the first stages of evolution (McClay \& Dooley, 1997; Rahe et al., 1998; Wu et al., 2009). These models show that, as accumulated displacement increases, the secondary fault splays evolve to accommodate more slip and progressively link to one another. In time, the secondary fault splays may unite to form the principal deformation zone, linking the two side-wall fault and abandoning the step-over fault geometry (Zhang et al., 1989; Dooley \& McClay, 1997; Rahe et al., 1998; McClay \& Bonora, 2001; Wu et al., 2009). Therefore, as strike-slip faults mature, longer fault segments will develop.

The present study focuses on the East Anatolian Fault (Fig.1) and more particularly on the Hazar Basin, a localised transtensional zone located in its central part (Hempton, 1980; Hempton \& Dewey, 1981; Hempton, 1982; Hempton et al., 1983; Mann et al., 1983; Hempton \& Dunne, 1984; Şengör et al., 1985; Muehlberger \& Gordon, 1987; Şaroğlu et al., 1992; Westaway, 1994; Çetin et al., 2003). This basin was the locus of a multidisciplinary fieldwork campaign in the summers of 2006 and 2007 with the objective of investigating its structure and sediments. This paper discusses the structure of the Hazar Basin and the implications for our understanding of the central section of the East Anatolian Fault. The structure of the basin is analysed utilizing bathymetric maps and seismic profiles collected from Lake Hazar in combination with the available geomorphological data of its surroundings. Several isopach maps, based on selected seismic horizons, are used to unravel the evolution of the Hazar Basin and evaluate the dynamic interaction between deformation and sedimentation in the basin. Finally, a minimum age of the 
present structure of the Hazar Basin is estimated based on the cumulated left-lateral deformation of the northeastern half of Lake Hazar.

\section{Tectonic setting}

The westward extrusion of the Anatolian plate towards the Aegean subduction zone is the most prominent neotectonic feature of Turkey (Fig. 1). This extrusion started 12 Ma ago (Dewey et al., 1986; McQuarrie et al., 2003) as a result of the collision of the Arabian and Eurasian plates (McKenzie, 1972; Dewey \& Şengör, 1979; Jackson \& McKenzie, 1988). Presently, the extrusion of the Anatolian plate is predominantly accommodated by the East and North Anatolian Fault zones (McClusky et al., 2000; Hubert-Ferrari et al., 2002; Reilinger et al., 2006).

The left-lateral East Anatolian Fault marks the 600 km long strike-slip boundary between the Arabian and Anatolian plates (Arpat \& Şaroğlu, 1972). It strikes NE-SW linking the leftlateral Dead Sea Fault to the right-lateral North Anatolian Fault (Fig. 1). The East Anatolian Fault has an average slip rate of $10-11 \mathrm{~mm} / \mathrm{yr}$ (Çetin et al., 2003; Reilinger et al., 2006), a total offset of 15 - $30 \mathrm{~km}$ (Şaroğlu et al., 1992; Westaway, 1994, 2003) and an estimated age of $3-4$ Ma (Barka, 1992; Şaroğlu et al., 1992; Westaway \& Arger, 1996; Hubert-Ferrari et al., 2008). The fault trace is segmented with a maximum recognised segment length of $\sim 100 \mathrm{~km}$ (Muehlberger \& Gordon, 1987; Barka \& Kadinsky-cade, 1988; Şaroğlu et al., 1992). These characteristics of the East Anatolian Fault, compared to other major strike-slip plate boundary faults, indicate that it is relatively immature. For example, the North Anatolian Fault has generated earthquakes with magnitudes of $\sim 8$ associated to $\sim 300 \mathrm{~km}$ long surface ruptures (Ambraseys \& Finkel, 1995; Barka, 1996), while the largest known earthquake on the East Anatolian Fault had a maximum magnitude of only 7.4 (Ambraseys, 1989; Nalbant et al., 2002). This difference in earthquake magnitudes and rupture length between the East and North Anatolian Faults reflects the greater maturity of the latter. Indeed, the North Anatolian Fault has a 
higher slip rate of 20 - 25 mm/yr (McClusky et al., 2000; Hubert-Ferrari et al., 2002; Kozaci et al., 2007), a larger total offset of about $85 \mathrm{~km}$ (Armijo et al., 1999; Bozkurt, 2001; Westaway \& Arger, 2001; Hubert-Ferrari et al., 2002; Şengör et al., 2004), and an older age of 10 - $12 \mathrm{Ma}$ (Barka, 1992; Şengör et al., 1985, 2004).

The East Anatolian Fault zone was first interpreted as an oblique collision belt (e.g. Lyberis et al., 1992) because its location at the front of the Arabian plate and along the Tauride mountain range, which follows the Neotethys suture (McQuarrie et al., 2003; Robertson et al., 2006). However, according to an S-wave receiver study (Angus et al., 2006), the deep Arabian lithosphere is not present underneath Anatolian. Indeed, GPS data show a dominantly left-lateral strike-slip motion associated with this fault zone (McClusky et al., 2000; Reilinger et al., 2006). The left-lateral East Anatolian Fault thus appears to be the actual boundary between the Arabian and Anatolian plates. Transpressional and transtensional deformation do exist locally, although in association with fault discontinuities (e.g. Westaway 1994, 1995, 2003). The strike-slip nature of this fault is confirmed in the central part of the East Anatolian Fault by the focal mechanisms calculated for the recent seismicity of this area (Fig. 2). Nevertheless, active thrust deformation is evidenced to the south of the East Anatolian Fault at the boundary between the Tauride belt and the Arabian platform by the occurrence of a Ms 6.7 thrust earthquake in Lice in 1975 (Taymaz et al., 1991; Örgülü et al., 2003; Tan et al., 2008) and by the geomorphological study of Cowgill (2007).

The East Anatolian Fault has a complex fault trace (Fig. 1), particularly at its northern and southern extremities, where it intersects the North Anatolian and Dead Sea Faults respectively (Şaroğlu et al., 1992; Koçyiğit et al., 2001). Previous studies have recognised three major discontinuities on its trace, from northeast to southwest: 1) the Bingol area, 2) the Hazar Basin and 3) the Sincik area (See Fig. 1) (Hempton, 1982; Hempton et al., 1983; Dewey et al., 1986; 
Şaroğlu et al., 1992; Koçyiğit et al., 2001; Çetin et al., 2003). There are, however, many others minor fault discontinuities leading to several alternative interpretations of fault segmentation (e.g. Barka \& Kadisky-Cade, 1988). This fault zone has ruptured over most of its length during the $19^{\text {th }}$ century in a series of magnitude $\sim 7$ earthquakes (Ambraseys, 1989, 1997; Ambraseys \& Jackson, 1998; Nalbant et al., 2002). Two of these large earthquakes occurred in the vicinity of Lake Hazar in 1874 and 1875, for which surface-wave magnitudes have been estimated to be 7.1 and 6.7 respectively (Ambraseys, 1989; Ambraseys \& Jackson, 1998). According to Ambraseys (1989), these earthquakes affected a very large region (See isoseismal lines in Fig. 1) and caused particularly severe damage in the Hazar area, uplifting significantly the southeastern outlet of the lake (Fig. 3). As a result, the lake outflow into the Tigris River ceased and the lake level rose (Ambraseys, 1989). These earthquakes were also described by Çetin et al. (2003), who found evidence of the 1874 and/or the 1875 earthquakes in one of the trenches opened on the Gezin Fault, which is located in the southeastern extremity of the Hazar Basin (Fig. 3). According to that study, the 1874 event was produced by a rupture of the Havri Fault (Fig. 3), possibly over a distant of $130 \mathrm{~km}$. In order to explain such a long rupture, Çetin et al. (2003) propose a possible joined rupture of the Palu-Hazar and Hazar-Sincik segments (Fig. 2) during this event. Indeed, previous studies have suggested that both segments may be connected (Şaroğlu et al., 1992) or, even, may form one continuous fault segment (Muehlberger \& Gordon, 1987) and are, thus, able to rupture at the same time. However, none of these interpretations of the fault geometry have been proved yet. Çetin et al. (2003) also indentified two other events associated to this section of the East Anatolian Fault: one occurred after AD 1420 (probably the 03/28/1513 earthquake of Ms $\geq 7.3$ described by Ambraseys (1989)) and another in AD 250 - 450. In addition to those earthquakes, two other large historical earthquakes have been reported from the Palu-Hazar area: one in AD 995 and another in AD 1789, both with estimated Ms $\geq 7.0$ (Ambraseys, 1989; Guidoboni et al., 1994; Ambraseys \& Jackson, 1998). Nevertheless, during the $20^{\text {th }}$ century the 
East Anatolian Fault has been less active with only two events of magnitude $>6$ occurring near Malatya in 1905 and northeast of the Bingol Basin in 1971 (Taymaz et al., 1991; Ambraseys, 1989; Kekovali et al., 2003; Tan et al., 2008). This absence of large earthquakes has resulted in relatively little attention being paid to the East Anatolian Fault compared to the North Anatolian Fault, which has rupture during the last century in several earthquakes of Ms $\sim 7$ (e.g. Barka, 1996; Stein et al., 1997). However, the historical seismic activity (Ambraseys, 1989) and the present GPS based strain rate (McClusky et al., 2000; Reilinger et al., 2006) indicate that the East Anatolian Fault is a major potential source of high-magnitude earthquakes. Moreover, considering the large population and infrastructure (Tosun et al., 2007) within the potential seismic damage zone (Fig. 1 \& 2), the East Anatolian Fault zone poses a significant seismic hazard.

\section{Site Description}

The Hazar Basin is a $25 \mathrm{~km}$ long, $7 \mathrm{~km}$ wide intra-mountain sedimentary basin located in the central part of the East Anatolian Fault (Figs. 1 \& 2) at a mean elevation of $1250 \mathrm{~m}$ (Hempton $e t$ al., 1983). The southern margin of this basin is steep and dominated by Mount Hazar (2350 m), while the northern margin has relatively low relief (maximum of 1685_m) and generally gentle slopes. Lake Hazar covers about $100 \mathrm{~km}^{2}$ of the basin area with a NE-trending elongated-shape along the East Anatolian Fault (Figs. 2 \& 3). The relatively straight southern edge of the lake runs along the base of Mount Hazar and is considered to be fault controlled, while the northern coastline, which is more irregular, is not (Hempton, 1982, Hempton et al., 1983, Hempton \& Dunne, 1984). The Hazar Basin is generally described as a pull-apart basin with a left-lateral stepping separation of $\sim 3 \mathrm{~km}$ between the Palu-Hazar and Hazar-Sincik segments (Hempton, 1980; Hempton \& Dewey, 1981; Hempton, 1982; Hempton et al., 1983; Mann et al., 1983; Hempton \& Dunne, 1984; Şengör et al., 1985; Şaroğlu et al., 1992 Westaway, 1994; Çetin et al., 
2003). An alternative interpretation of the Hazar basin structure has been proposed by Aksoy et al. (2007), who suggest that the Hazar Basin is the result of a negative flower structure. Nonetheless, none of these interpretations have actually been demonstrated, as the structure inside Lake Hazar has remained unknown until the present study.

The onland fault geometry of the East Anatolian Fault comprises two sub-parallel main fault strands at the east of Lake Hazar, named the Havri Fault (northern strand) and Gezin Fault (southern strand) by Çetin et al. (2003) (see also Hempton et al., 1983; Hempton \& Dunne, 1984; Şaroğlu et al., 1992). The Havri Fault is very straight, striking $\mathrm{N}^{\circ} 5^{\circ} \mathrm{E}$ near the lake shore, and has accommodated $175 \mathrm{~m}$ of left-lateral slip in the last 14,750 - 15,255 years (Çetin et al., 2003). The Gezin Fault has a slightly different strike and dips toward the Havri Fault. The Gezin Fault accommodates some normal motion as attested by: 1) a north-dipping fault scarp, 2) active sedimentary infilling on the downthrown northern block, and 3) hanging valleys on the tilted southern upthrown block. According to Çetin et al. (2003), these characteristics suggest a cumulative vertical offset of at least 140 m. West of Lake Hazar, the East Anatolian Fault zone comprises two main sub-parallel fault strands as well (Hempton, 1982; Hempton et al., 1983; Hempton \& Dunne, 1984; Şaroğlu et al., 1992; Aksoy et al., 2007). The fault morphology is less clear here than in the east because of the greater geological complexity. This site is characterized by a "megabreccia zone" outcropping in between the two fault strands, which Hempton (1982) associated with left-lateral shear between these two sub-parallel faults. The $\mathrm{N} 63^{\circ} \mathrm{E}$-striking Southwestern Fault (SwF in Fig. 3) accommodates mainly strike-slip deformation (Hempton, 1982; Hempton et al., 1983), as evidenced by the presence of left-laterally offset streams, pressure and shutter ridges and sag pond structures along its trace. Whereas, the sub-parallel Northwestern Fault (NwF in Fig. 3), which strikes $\mathrm{N}^{\circ} 6^{\circ} \mathrm{E}$, might accommodate some vertical motion. This is attested by a north-dipping scarp along its trace and was corroborated by 
observations in a test-pit excavated across this fault during summer of 2007 (Fig. 3). Many previous studies (Hempton, 1982; Hempton et al., 1983, Şaroğlu et al., 1992; Çetin, 2003; Aksoy, 2007) mapped an additional fault system on the northern flank of Mount Hazar striking nearly parallel to the southern coastline of Lake Hazar. This fault system was recognised during fieldwork forming two 150 - $200 \mathrm{~m}$ high and $\sim 4 \mathrm{~km}$ long segmented scarps (Fig. 3). These scarps have generally been attributed to normal faulting (e.g. Çetin et al., 2003; Aksoy et al., 2007). Hempton (1982) noted that this fault separate blocks of contrasting lithology with most of their slickenside indicating oblique-slip. Nevertheless, the origin and relationship of this fault with the basin structure are uncertain and beyond the scope of the present study.

Basin sediments are predominantly sourced from two main drainage systems discharging into the lake at its southwestern and northeastern ends (e.g. Hempton et al., 1983). The northeastern drainage system comprises several streams with small drainage areas, whereas the southwestern system is mainly dominated by the Kürk River, which drains a large area and forms a significant alluvial fan at the southwestern coast of the lake (Fig. 3). This river is presently incised into the fan surface by about $2-3 \mathrm{~m}$ following the Northwestern Fault, which cuts the southern part of the fan (Hempton et al., 1983).

\section{Methodology}

The geophysical study of Lake Hazar consisted of a high-resolution seismic reflection survey, which was complemented with side-scan sonar data. In total, 44 seismic profiles were collected along a $\sim 500 \mathrm{~m}$ spaced grid (Fig. 3). The acquisition system consisted of a "centipede" multielectrode sparker, as acoustic source (300 J and main frequency of $400-1500 \mathrm{~Hz}$ ), and a 10hydrophone single-channel streamer, with active length of $2.7 \mathrm{~m}$, as receiver. Precise navigation data was provided by means of a SIMRAD Shipmate GPS system and recorded, together with the 
seismic signal, by an ELICS Delph-2 system, and subsequently converted to SEGY format. Bathymetry and structural maps were constrained by interpolation of the seismic lines assuming a sound velocity in water of $1500 \mathrm{~m} / \mathrm{s}$ and $1600 \mathrm{~m} / \mathrm{s}$ in soft sediments. The side-scan sonar survey used a KLEIN 3000 device that simultaneously recorded in two frequency bands of 100 and 500 kHz. Towfish depth regulation was done manually. The objective of the side-scan sonar survey was to detect abrupt morphological variability of the lake floor, such as fault scarps.

In order to unravel the structure of the Hazar Basin, the seismic profiles were analysed to identify the main faults using interpretation criteria such as localised vertical offset of seismic reflections, growth strata and the presence of hyperbolic diffractions created at the fault planes. Relative fault activity and deformation style were estimated by the amount of vertical offset and deformation of the seismic reflections near the fault plane, scarp geomorphology and fault continuity across different seismic profiles. Interpretations of scarp geomorphology and fault length were aided by the side-scan sonar data. Faults splays are classified as main, secondary, or minor strands according to their length, damage zone and relative amount of offset. Finally, thirteen seismic horizons were mapped throughout most of the seismic profiles in order to reveal temporal patterns of sediment-deposition and to provide insight into the structural evolution of the basin. These seismic horizons either represent unconformities or marker horizons with characteristic amplitude or frequency attributes. They were correlated across the seismic grid according to their continuity through intersections between different seismic profiles crossing one another. Correlations across the Master Fault were made in the central part of Lake Hazar, where the vertical offset along this fault is smaller than in others sectors of the lake and seismic units can easily be compared from one sub-basin to another. 


\section{Results \\ 5. 1. Bathymetry and present-day fault distribution in Lake Hazar}

The bathymetry map (Fig. 4) shows two distinct areas: an irregular $216 \mathrm{~m}$ deep sub-basin in the northeastern half of the lake and a much flatter and shallower sub-basin occupying its southwestern half. These two main sub-basins have been named the Deep and Flat basins to facilitate the description of the basin. Three additional bathymetric features stand out, which are from east to west: 1) a plateau locally separating the Deep Basin from the southern lake margin, 2) a small $140 \mathrm{~m}$ deep elongated basin located northwest of the plateau and southwest of the Deep Basin and 3) a promontory situated south of the Flat Basin, from which the Kilise Adasi Island emerges (Fig. 4).

We describe the structure revealed by the seismic investigation from west to east. The Southwestern and Northwestern faults described onshore correlate to the Master Fault and Northwestern Splay inside the lake, respectively (Fig. 4). Both faults converge at the northeastern corner of the promontory giving rise to shortening features probably associated with the bend of the Northwestern Splay towards the Master Fault (Fig. 4). To the southeast of their junction, a north-dipping fault (the Southern Fault) is recognised along the southern margin of the lake composed of several complex splays. This fault continues onshore as the aforementioned Gezin Fault forming a continuous $\sim 24 \mathrm{~km}$ long fault strand. Near the centre of the lake, a splay of the Master Fault forms a depression revealed in the bathymetry as the Small-elongated Basin (SeB in Fig. 4), which is clearly recognisable in the side-scan sonar data (Fig. 5). In the northern quartile of the lake, a south-dipping fault (the Northern Fault) arcs for $8 \mathrm{~km}$ around the northern edge of the Deep Basin. This fault has a conjugate strand in places and forms localised graben structures. At its western end, the Northern Fault curves toward the Master Fault forming a scarp about $18 \mathrm{~m}$ 
high that is visible in the side-scan sonar data (Fig. 5a). At the northeast end of the lake, the Northern Fault converges with the Master Fault, which correlates to the Havri Fault onshore (Fig. 4). Therefore, the Southwestern, Master and Havri Faults are part of the same continuous fault strand. In the northeast half of the lake, this continuous Master Fault strikes at $6^{\circ}$ rotated counterclockwise relative to its onshore continuation, the Havri Fault, revealing a subtle releasing bend geometry (see Mann et al., 1983, 1995; Cunningham \& Mann, 2007) in this area (Fig. 4).

\section{2. Deep faulting characteristics and basin structure}

A representative set of six seismic profiles (Fig. 6) has been selected to characterize the different fault systems and subsurface structures corresponding to the morphostructural features described in the previous section. The selected profiles are not located near the eastern and western ends of the lake because of the poor seismic penetration in those areas (see locations in Fig. 4). All the profiles are plotted with a vertical exaggeration of $\sim 8$.

Different seismic units were identified on the seismic profiles bounded at top and bottom by seismic horizons 1 to 12 . The seismic facies of these units are mostly acoustically well-stratified, with characteristic successions of high- and low-amplitude parallel reflections (e.g. Fig. 6a). At the base of this seismic sequence, an additional seismic unit is present, characterized by a chaotic to diffuse seismic facies (e.g. Fig. 6b), although some individual reflections can be discerned in it. The boundary between the acoustically stratified and the chaotic to diffuse seismic units is consistently marked by a set of strong reflections distinguishable on most of the seismic profiles. This paper focuses on the seismic sequence above the chaotic to diffuse seismic unit. We refer to it as the "lacustrine infill", while we refer to boundary between this seismic sequence and the chaotic to diffuse seismic unit as the "base of the lacustrine infill". Notice that the term "lacustrine infill" does not necessarily imply that the diffuse seismic unit underneath was not 
deposited in a lacustrine environment. It only indicates that the upper, acoustically well-stratified seismic unit has most likely been deposited in an open lacustrine environment, while the acoustically massive seismic unit below it could have been deposited either in a terrestrial or in a lacustrine environment. The base of the lacustrine infill is displayed on the profiles analyzed in this section together with twelve other prominent seismic reflections, labelled horizons 1 to 12 (Fig. 6).

Profile 17 (Fig. 6a) crosses the Deep basin at its centre (Fig. 4). It shows a deep infilled basin bounded by steep sidewall faults, the Northern and Southern faults, and divided in its centre by the Master Fault. The steep slopes enclosing the basin are considered to be fault controlled because of the geometry of the reflection terminations, the lateral continuity of these structures and the presence in other profiles of features typically related to fault activity, such as growth strata and nearby minor faults associated to them both (see Fig. 6b). This interpretation is also corroborated by the alignment of the southern fault-like structure to the onshore Gezin Fault (Fig. 4), which is considered as its onshore continuation. In addition, the Northern and Southern faults appear to be predominantly extensional in character, which is in agreement with the apparent vertical offset measured along the Gezin Fault (Çetin et al., 2003). Contrarily, the Master Fault is identified as being principally strike-slip in character. This interpretation is supported by the alignment of this feature with two main strike-slip faults onshore (Fig. 4) and by the fact that lateral changes in dip direction of the fault occur from one profile to another. The Master and Southern faults are characterized in this profile by narrow and simple fault zones, while the Northern Fault zone is wider with two conjugate splays separated by about $300 \mathrm{~m}$. The fault dip angles shown in this profile (taking into account a vertical exaggeration of $\sim 8$ ) are similar across the entire Deep Basin: the Northern and Southern faults are steeply dipping $\left(50^{\circ}\right.$ to $\left.65^{\circ}\right)$, while the Master strike-slip fault is near vertical $\left(>80^{\circ}\right)$. The uppermost seismic unit (above $\left.\mathrm{H} 1\right)$ comprises 
reflections of much higher amplitude than those below. This unit is slightly curved upward against the Northern and Southern faults, although much less than the seismic units below it that forms an unconformity close to the fault zones with its base (H1). This increase in deformation with depth may be indicative of continuous tectonic activity along both fault systems. The Master Fault clearly offsets the uppermost seismic reflections forming a $\sim 6 \mathrm{~m}$ high, down-to-the-north, scarp on the lake floor, attesting to its recent activity. The basin can be divided in two sub-basins north and south of the Master Fault, each having distinct structures. The infill of the northern subbasin forms an asymmetric subtle syncline with an axial plane $\sim 550 \mathrm{~m}$ north of the Master Fault and a visible lacustrine infill of $240 \mathrm{~m}$ thick. The base of the lacustrine infill is not observed on this side of the profile. The southern sub-basin has much flatter bedding and the base of the lacustrine infill is found close to the Southern Fault revealing a minimum thickness of $220 \mathrm{~m}$. The seismic-stratigraphic architecture of the southern sub-basin is marked by a change in the geometry of the seismic reflections between Horizon $6(\mathrm{H} 6)$ and $8(\mathrm{H} 8)$, which appears to correspond to the burial of a set of faults located to the north of the Southern Fault (Fig. 6a). The difference in geometry of the two sub-basins may reflect lateral juxtaposition of parts of the basin that did not form adjacently. Indeed, the thickness of equivalent seismic units is $\sim 1.4$ times larger in the northern sub-basin than in the southern one. Nevertheless, the difference in thickness is also coincident with the down-to-the-north displacement of the lake floor, which may indicate some vertical offset at this location. That is in agreement with the releasing-bend geometry defined by the Master Fault (Fig. 4), which would favour subsidence of the northern sub-basin with respect of the southern one.

Profile 40 (Fig. 6b) is located $3.35 \mathrm{~km}$ east of profile 17 (Fig. 6a) crossing the western part of the Deep Basin and the plateau (Fig. 4). Comparison of these two profiles highlights the high variation in fault geometry and basin structure along strike. The same three active fault systems 
are recognised, although they have wider fault zones and are more complex in profile 40 than further east (e.g. Fig. 6a). The Master Fault system comprises two major semi-parallel splays (Mfa and Mfb) separated by about $250 \mathrm{~m}$ on the lake floor. Mfa is nearly vertical and limits the Deep Basin or northern sub-basin to the southeast. This strand is at the base of a $40 \mathrm{~m}$ high northfacing scarp, which is probably predominantly formed by left-lateral displacement because this magnitude of displacement was not recognised on profile 17. Mfb dips toward Mfa and defines the northern extent of the plateau. Mfb displays no apparent scarp on the lake floor. However, it significantly offsets the whole sedimentary infill, including the uppermost seismic reflections, indicating a relatively recent activity. The Southern Fault system also comprises several splays. The main splay of this fault system is separated from the southern slope by $400 \mathrm{~m}$ and forms a 4 $\mathrm{m}$ high scarp on the lake floor, which together with the development of growth strata on its downthrown northern block (Fig. 6b), attest to its recent activity. At depth, this splay forms a broader fault zone towards which the sedimentary infill of the southern sub-basin is tilted. The seismic horizon H1 lies nearly horizontally on top of these tilted seismic units defining a sharp angular unconformity. In this part of the profile, between the main splay of the Southern Fault and the southern slope, a lens-shaped seismic body composed of chaotic reflections suggests the occurrence of land-slides in this area in the period of deposition of H4 to H1. The Northern Fault zone is about $400 \mathrm{~m}$ wide at depth and consists of several fault splays. Near the surface, two main splays are recognised composing this system with an apparent dip of $60^{\circ}$ to $65^{\circ}$ to the south. These faults do not extend to the surface, although the southern splay and an antithetic strand north of it produce a subtle anticline affecting the uppermost seismic reflections. In this profile, the infill of the northern sub-basin still forms a subtle (notice the vertical exaggeration) asymmetrical syncline with about $300 \mathrm{~m}$ of sediments above the base of the lacustrine infill. The comparison between the same set of seismic horizons in profiles 17 and 40 shows that equivalent seismic units are about 3 times thicker in the northern sub-basin on profile 17 (Fig. 6a) than on 
profile 40 (Fig. 6b). Extrapolating this ratio, a minimum lacustrine infill of about $900 \mathrm{~m}$ is inferred in the central part of the Deep Basin (e.g. profile 17). In profile 40, the southern subbasin (beneath the plateau) has a similar geometry as revealed in profile 17 , but with a thinner lacustrine infill, which reaches about $100 \mathrm{~m}$ in its centre.

Profile 22 (Fig. 6c) images the small-elongated basin and is located near the transition from the Deep Basin to the Flat Basin (Fig. 4). The main structural change with respect to profiles 17 and 40 is the concentration of most of the deformation on the Master Fault system. The Northern Fault, less active here, forms a broad zone of buried faults with the main strand extending to near the surface and slightly offsetting the uppermost seismic reflections. This fault system strongly affects the reflections situated in between the base of the lacustrine infill and H11, making it difficult to identify individual horizons in this zone. The Southern Fault, like in profiles further west, forms a discrete limit of the southern sub-basin with no scarp or associated growth strata. The Master Fault defines a $500 \mathrm{~m}$ wide negative flower structure dominated by three main fault splays, all of them forming significant scarps on the lake floor clearly identifiable with the sidescan sonar data (Fig. 5a). The main strand of the flower structure (Mfa) is vertical and located in the centre of the fault system. The other two strands (Mfb and Mfa') bound the small-elongate basin and dip $\sim 75^{\circ}$ toward the Mfa. The seismic reflections in the northern and southern subbasins are tilted toward the Master Fault revealing a strong localised subsidence, which is possibly associated to the transtension concentrated at the flower structure. Profile 22 (Fig. 6c) also shows that the lacustrine infill of the northern sub-basin becomes thinner to the west. Moreover, there is a complete inversion of the sub-basins morphology with respect to profile 40 (Fig. 6b) and 17 (Fig. 6a): the infill of the northern sub-basin is now thinner $(80 \mathrm{~m})$ than the southern one $(120 \mathrm{~m})$. This along-strike inversion of the basin morphology and structure between 


\begin{abstract}
the northern and southern sub-basins is possibly linked to their translation along the left-lateral Master Fault.
\end{abstract}

Profile 34 (Fig. 6d), as profiles 4 (Fig. 6e) and 29 (Fig. 6f), reveals a Flat Basin limited to the south by the principal deformation zone and to the north by a non-fault-controlled margin. In these profiles, the strata of the Flat Basin are sub-horizontal and dip gently toward the south. The total lacustrine infill of the Flat Basin is thinner $(66 \mathrm{~m})$ in profile 34 compared to the $\sim 80 \mathrm{~m}$ on profiles 4 and 29. This difference in sedimentary thickness probably reflects variations in sediment supply as discussed in the following section of this paper. In Profile 34 (Fig. 6d), the Flat Basin is bounded to the southeast by the upward-steepening, apparently southeast-dipping Master Fault, which rolls over near the lake floor. The geometry of the strike-slip Master Fault suggests that there may be some transpression in this area. This is corroborated by the presence of a pop-up structure limited by the Master fault to the north and by a downward-concave slopebreak, which may reflect an unrecognised fault, to the south. To the southeast of this structure, the lake floor forms a depression where little sub-surface structure is revealed by the seismic data. Nonetheless, two possible faults are recognised in this area, which may be related to the western extremity of the Southern Fault system.

Profile 4 (Fig. 6e) is quite similar to profile 34 (Fig. 6d) northwest of the Master Fault, although a single sub-vertical fault extends considerably higher in the strata of the Flat Basin than the faults identified in profile 34 at that location. An interesting feature related to this sub-vertical fault is the presence of some amplitude anomalies that may be caused by pockets of free gas accumulations, suggesting fluid migration along the fault plane. The southeastern edge of the Flat Basin is deformed by a pair of southeast-dipping faults with an apparent reverse displacement. The main strand of this apparently reverse system, the Northwestern Splay, coincides with the base of the promontory, which forms a steep slope bounded to the southeast by the Master Fault. 
The overall image revealed by the pattern of faulting is that of a positive flower structure coinciding with the elevation of the promontory. Therefore, the promontory might be a result of this transpressional feature. However, it has not been possible to verify this assumption, as the acoustic reflection in the promontory is diffuse and gives no insight into the sub-surface strata.

Profile 29 (Fig. 6f) shows a similar structure to the one revealed by the previous profile (Fig. 6e). However, the faulting in the Flat basin extends into shallower strata and the positive flower structure is wider and presents higher fault complexity than in profile 4 (Fig. 6e). The Northwestern Splay $(\mathrm{NwS})$ is located at $800 \mathrm{~m}$ to the north of the Master Fault and separated from the latter by a piggy back basin. To the south of the Master Fault several minor faults are recognised defining the southern part of the flower structure. The main fault of this southern system, as the Master Fault and Northwestern Splay, forms a significant scarp on the surface, attesting to the present-day activity of this structure.

\section{Sedimentation}

Even though the sediment cores collected from Lake Hazar will be the topic of another publication, we will here discuss the sedimentation rates derived from the core analysis. Radiocarbon and radionuclide $\left({ }^{137} \mathrm{Cs}\right.$ and $\left.{ }^{210} \mathrm{~Pb}\right)$ dating of eight $1 \mathrm{~m}$ short cores and two $5.25 \mathrm{~m}$ long cores collected in the central part of the Flat Basin suggest a sedimentation rate of $\sim 1 \mathrm{~mm} / \mathrm{yr}$ for this area of the lake. The cored sediments mainly consist of thick (several centimetres) clay units alternating with a few $\sim 1 \mathrm{~cm}$ thin silt to fine sand units, indicating sporadic changes in the sedimentations settings of the lake probably linked to the seismic activity of this area. The cores have sampled the upper $\sim 10 \mathrm{~m}$ thick seismic unit (Fig. 7), which clearly stands out on all seismic profiles because of its higher-amplitude seismic facies and the unconformity defined by its base (H1) (Figs. 6 \& 7). Assuming the long term applicability of the sedimentation rate derived from 
the uppermost sediments, seismic horizon $\mathrm{H} 1$ was at the surface about $10 \mathrm{ka} \mathrm{BP}$, suggesting that this seismic horizon represents the base of the Holocene. The unconformity defined by H1 becomes more pronounced towards the northern and southern margins of the Flat Basin (Fig. 7), which might indicate the occurrence of erosion at these areas during a former lowstand of the lake. At the northern slope, the lake floor forms a subtle step where the uppermost reflections are also unconformable with respect to the underlying ones. This feature is recognizable at $40 \mathrm{~m}$ deep in most of the seismic profiles (Fig. $6 \& 7$ ) and might indicate a relatively recent lowstand of the lake level (see also the discussion section of this paper).

The supply of sediment into the Hazar Basin is largely controlled by the drainage network that discharges into Lake Hazar. Figure 8 shows the stream system around the lake and, within the lake, the thickness of the Holocene sedimentary unit in swaths along the seismic lines (isopach map of sediments between the lake floor and horizon H1). The drainage system of the Hazar Basin is elongate along the East Anatolian Fault (Fig. 8), with the principal sources of sediments located in the southwestern and northeastern ends of the lake. The sedimentation in the central part of the basin is mainly controlled by many minor ephemeral streams draining the southern and northern slopes of the basin. Especially important are those streams located at the base of Mount Hazar, which are associated with active depositional systems on the southern margin of the lake (Hempton et al., 1983; Hempton \& Dunne, 1984; Dunne \& Hempton, 1984). Mount Hazar is heavily coated with snow in winter and the annual melt probably causes the annual peak stream flows. The asymmetric sedimentary supply of the lake is reflected in the penetration of the acoustic signal. The lack of seismic penetration in some areas (e.g. Fig. 6d) of Lake Hazar spatially correlates to the major sediment supplies onshore. We therefore infer that the poor seismic penetration in those areas may be the result of biogenic gas production associated with terrestrial organic matter in the deposits. The sedimentary infill of Lake Hazar 
also reflects this asymmetric sedimentary supply. The lacustrine infill is minimal in the central part of the basin (See profiles 22 and 34 in Figs. 6c \& d) with respect to both extremities (Profiles 17 and 29 in Figs. $6 a$ \& f).

The Holocene isopach map highlights the influence of the different tectonic structures on the sedimentation in the basin (Fig. 8). The extensional regime dominating the northeastern part of the basin has created accommodation space to effectively trap sediments and the highest sedimentation rate occurs in that area. Indeed, the thickest sedimentary infill is located to the northeast of the Deep Basin due to the presence of the releasing bend formed by the Master Fault and the geometry defined by this fault and the convergence of the Northern Fault toward it. The thickness of the Holocene infill decreases to the southwest, being minimum in the centre of the basin, to increase again significantly further west due to the influence of the western fan delta. There, sediments are preferentially trapped in the front of the positive flower structure situated to the south of the Flat Basin (Fig. 8). Hence, the sediment distribution and basin formation inside Lake Hazar is strongly influenced by the structure and active deformation affecting the basin.

\section{Basin Evolution}

Three isopach maps are compared with the Holocene sedimentation pattern to investigate the recent evolution of the basin. These isopach maps show the thickness between seismic horizons $\mathrm{H} 3-\mathrm{H} 1, \mathrm{H} 5-\mathrm{H} 3$ and $\mathrm{H} 9-\mathrm{H} 5$ (Fig. 9a to 9c). The seismic horizon pairings were selected due to their continuity throughout the seismic profiles (Fig. 6).

The H3 - H1 isopach map (Fig. 9a) reveals a sedimentation pattern similar to that of the Holocene (Fig. 8). The thickest sedimentary infills are located in the Deep Basin and around the small-elongated basin, while notably less sedimentation is evident in the Flat basin. The Deep Basin is characterized by a thick sedimentary infill between the southern and northern sidewall 
faults, with the depocentre located in the northern sub-basin at the northeastern end of the lake and at exactly the same place as during the Holocene. Therefore, the tectonic regime has been relatively constant since the deposition of H3 to the present. The Deep Basin is clearly offset, although the isopachs show variations in deformation from one line to another making it impossible to quantify the amount of offset during this period of time.

The H5 - H3 isopach map (Fig. 9b) shows a constant relatively thin package of sediments across the basin, except for a subtle increase in thickness in the central part of the Deep Basin. The main depocentre is located about $900 \mathrm{~m}$ southwest of its position during the Holocene and $\mathrm{H} 3-\mathrm{H} 1$, indicating an apparent southwest migration of the depocentre over time. Notably, there is no sedimentation anomaly associated with the small-elongated basin due to the impossibility to map the relevant reflections within this structure. However, the seismic profiles crossing it (e.g. Fig. 6c) show that both horizons are deformed by the main fault splays forming the smallelongated basin. Therefore, the negative flower structure was active during the deposition of H5 and $\mathrm{H} 3$.

The H9 - H5 isopach map (Fig. 9c) reveals a thin sedimentary infill, similar to that of the H5 - H3 isopach map, although with a more speculatively located depocentre in the Deep basin because of the lack of data to the northeast. Nevertheless, the depocentre appears to be located further west than in the previous isopach maps corroborating the apparent westward migration of the depocenter evidenced by comparison of the $\mathrm{H} 1-\mathrm{H} 3$ and $\mathrm{H} 5-\mathrm{H} 3$ isopach maps. The isopach map H9 - H5 shows thicker sedimentary infill close to the Southern Fault than along the Master Fault. Therefore, at that period of time the Master Fault may have accommodated less transtensional deformation than during the deposition of the seismic reflections above H5, being the highest dip-slip deformation associated to the Southern Fault system. This evolution was already noted in profile 17 (Fig. 6a), where there is a marked change in the seismic reflections 
geometry above H5 associated with the burial of previously active normal faults. Figure 10 shows the southeastern side of seismic profile 38 located 500 m west of profile 17 (see Fig. 4) and further highlights the variations in the infill geometry between the Master Fault and the Southern Fault over time. In the southern sub-basin, below H5 the thickest sedimentary infill is against the Southern Fault, whereas, above H5, the sedimentary infill is thicker against the Master Fault.

Another isopach map has been built between the base of the lacustrine infill and the lake floor to evaluate the total deformation of the imaged infill of the basin (Fig. 11). This isopach map shows the higher thickness located in the Deep Basin, which is consistent with the pattern of sedimentation revealed by the four isopach maps described above. It also reveals a consistent $\sim 3$ $\mathrm{km}$ left-lateral offset of the isopachs along the Master Fault. This deformation represents the total offset accommodated by the Master Fault since the base of the lacustrine infill was deposited. Following this line of reasoning, a rough estimate of the minimum age of the deformation can be made assuming that the average slip-rate on the East Anatolian Fault has been constant over time and close to the present-day $10 \mathrm{~mm} / \mathrm{yr}$ (Reilinger et al., 2006). According to these assumptions, the Deep Basin would have been left-laterally offsetting for at least the last $300 \mathrm{ka}$.

\section{Discussion}

\section{1. Recent lake-level fluctuations}

A subtle step (Fig. $6 \& 7$ ) has been mapped on the northern slope of the lake at $\sim 40 \mathrm{~m}$ deep (measured from the 2007 water level). This feature has been recognised at similar height and position in most of the seismic profiles. Based on its structure, widespread distribution and location, we believe that this feature was formed during a relatively recent lake-level lowstand. Indeed, Tonbul \& Yigit (1995) compiled historical data showing that the lake level was around 
$1220 \mathrm{~m}$ in AD 1807 and reached $1250 \mathrm{~m}$ in AD 1878. This lake-level increase may have had a tectonic origin. According to Ambraseys (1989), the AD 1874 - 1875 earthquakes uplifted the southeastern lake outlet by $4 \mathrm{~m}$, ending the outflow of the lake into the Tigris River (Ambraseys, 1989) and causing the lake level to rise. This suggests that other high-magnitude events, such as the AD 1789 earthquake, may also have affected the lake level significantly. In fact, an Armenian settlement occupied since AD 1200 and located in the southwestern outlet of Lake Hazar was abandoned shortly after the 1789 earthquake probably because of a lake-level rise (Özkan-Aygün, 2006). This settlement is presently located near the Kilise Adasi Island (Fig. 4) under $\sim 10 \mathrm{~m}$ of water with only two towers of the settlement gate emerging above the present (2007) lake level (Özkan-Aygün, 2006). Tectonic activity seems to be therefore the major factor for the lake-level rise during the late Holocene. Nonetheless, this factor may have been complemented by local or regional changes in the climatic conditions of this area. Indeed, Bookman et al. (2006) and Enzel et al. (2003) have related a water level rise in the Dead Sea during the late Holocene to an increase in humidity conditions of the regional climate of the eastern Mediterranean region.

The angular unconformity at the base of the Holocene unit (H1) observed in the seismic profiles (Figs. $6 \& 7$ ) might also represent a lowstand of the lake level that took place before the Holocene. This possible lake-level lowstand is in agreement with the change in climatic conditions occurred in this area between the last stage of the last glacial period and the early Holocene. According to Wick et al. (2003), the late stage of the last glacial period in eastern Anatolian was characterized by cold and very dry weather, while the Holocene has been more humid and warm. This climate change may have had a significant influence in the water-level of Lake Hazar favouring a lake-level rise during the early stages of the Holocene. However, this lake-level rise was most probably strongly controlled by the local tectonics, as shown by the case discussed above. 


\section{2. The Hazar Pull-apart basin}

The actual structure of the Hazar Basin shows that the main strike-slip fault recognised inside the lake corresponds to the offshore continuation of the Havri and Southwestern faults defining one main continuous fault through the Hazar Basin (Fig. 4). Presently, and at least for the last $300 \mathrm{ka}$, this fault represents the principal deformation zone of the Hazar Basin. The main depocenter of the basin is situated in the northeast of the Deep Basin where transtension is strongly favoured by the convergence of the Northern Fault toward the Master one and the releasing bend geometry developed by the latter fault at this location. The southern part of the Deep Basin is also accommodating some extension due to Southern Fault activity. However, the subsidence occurring south of the Master Fault seems to be less important at present than in past times (see Figs. 6a, $9 \& 10$ ). West of the Deep Basin, the basin formation is mainly controlled by the lateral and vertical offsets produced by the Master Faults and its splays with respect to the tectonically inactive northern margin of the basin.

Prior to $\sim 300 \mathrm{ka}$ the Hazar Basin may have comprised a fault step-over, but the penetration depth of our seismic investigation was not good enough to evaluate this possibility. However, the present-day structure of the Hazar Basin strongly resembles the latest phases of evolution of transtensional step-overs observed in analogue models (Dooley \& McClay, 1997; Rahe et al., 1998; Wu et al., 2009). Consequently, we believe that the Hazar Basin may have started its formation as a transtensional step-over or pull-apart basin that has evolved by linking its two sidewall faults and abandoning the step-over structure in favour of a continuous fault.

The structure of the Hazar Basin is not a particularity of this area. Indeed, similar structures have been observed forming others basins located on major strike-slip faults. For example, the Izmit Basin, which is situated in the western part of the North Anatolian Fault, also comprises an 
asymmetrical sub-basin bounded by two apparent normal fault systems and cut across by a bent strike-slip fault (Cornier et al., 2006). Consequently, based on the similarities between both basins, the structures of the Izmit and Hazar basins might have had similar evolutions.

\subsection{Implication of the Hazar Basin structure to the 1874 and 1875 earthquakes.}

The Hazar Basin has previously been considered as the location of a segment boundary because of the presumed step-over fault geometry of this area (Hempton, 1982; Hempton et al., 1983; Mann et al., 1983; Hempton \& Dunne, 1984; Şengör et al., 1985; Westaway, 1994; Çetin et al., 2003). However, the fault geometry revealed in this study debunks the justification of this interpretation. The main fault segments on either side of the Hazar Basin can now be considered as one fault segment extending continuously, in spite of minor discontinuities, between Palu and Sincik for $130 \mathrm{~km}$ (Fig 2 \& 4). Therefore, high-magnitude earthquakes, as the 1874 (Ms 7.1), are probably produced by ruptures of this Palu-Sincik segment. This interpretation is in agreement with the one proposed by Şaroğlu et al. (1992) and Muehlberger \& Gordon (1987) and with the $130 \mathrm{~km}$ long rupture suggested by Çetin et al. (2003), although the latter authors still interpreted the main fault discontinuous. According to Wells \& Coppersmith (1994), a fault segment of this length may imply a maximum moment magnitude of $7.5 \pm 0.3$. This estimation may indicate that the magnitude of the 1874 earthquake may have been underestimated. With regards to the 1875 earthquake (Ms 6.7), its lower magnitude and the rupture of the Gezin Fault reported by Çetin et al. (2003) occurring close in time with this event might indicate an independent rupture of the Southern Fault (the Gezin Fault) during this earthquake. However, the vertical offset produced in the southeastern outlet of the lake during this and the 1874 earthquakes and their similar damage distribution might also indicate a co-seismic rupture of the Master and Southern faults during both earthquakes. This situation of several fault systems close to each other rupturing co-seismically has been observed during large earthquakes in other 
natural settings. For example the Izmit-Gölük and Düzce earthquakes in Turkey (Barka et al., 1999; Emre et al., 2000) and the Kokoxoli earthquake in northern Tibet (Klinger et al., 2005).

\section{Conclusions}

The structural map established and discussed throughout this paper shows that the main strand of the East Anatolian Fault is continuous through the Hazar Basin. Therefore, the central part of this fault extends from Palu to Sincik without major discontinuities. Consequently, the present-day basin formation is not on account of a transtensional step-over, as was postulated in previous studies. Nevertheless, active transtension is recognised in the northeastern half of the Hazar Basin. There, two major extensional fault systems enclose a deep sub-basin (the Deep Basin) cut across by the continuous Master Fault, which forms an active releasing bend at the northeastern end of Lake Hazar. Based on the similarities of this structure and analogue models of pull-apart basin evolution, we propose that the present-day structure of the Hazar Basin derives from an initial transtensional step-over or pull-apart structure that was abandoned in favour of the through-going fault structure prior $\sim 300 \mathrm{ka}$.

According to the relationship between fault rupture and magnitude deduced by Wells \& Coppersmith (1994), we believe that the historical 1874 (Ms $~ 7.1$ ) earthquake was most probably caused by a rupture of the $130 \mathrm{~km}$ long Palu-sincik fault segment. Whereas, the lower-magnitude event of 1875 (Ms 6.7) may have been generated by an individual rupture of the $24 \mathrm{~km}$ long Southern Fault. Nevertheless, both earthquakes produced similar effects in the southern outlet of Lake Hazar and affected approximately the same area, which might indicate co-seismic ruptures of the Southern and Master faults during both earthquakes.

The lake level was $\sim 80 \mathrm{~m}$ lower at the start of the Holocene than in 2007 and may have reached its present height only during the last two centuries. These relatively recent lake-level 


\begin{abstract}
fluctuations appear to be mainly caused by tectonic forcing. However, the main rises of the lake level since the last glacial period are close in time with documented climatic changes in this region. Consequently, the climatic factor may also have contributed to the water-level rise of Lake Hazar during the Holocene period.
\end{abstract}

\title{
Acknowledgements
}

We acknowledge the European Commission for funding this project as part of the Marie Curie Excellence Grant Project "Understanding the irregularity of seismic cycles: A case study in Turkey" (MEXT-CT-2005-025617: Seismic Cycles). We thank Ronald Van der Linden, director of the Royal Observatory of Belgium, and Thierry Camelbeeck for their support to the present study. We also thank Koen De Rycker (Renard Centre of Marine Geology) and Emre Damci (Istanbul Technical University) for their inestimable work collecting the geophysical data on which this study is based. Finally, we would like to thank Erhan Altunel (Osmangazi University, Eskisehir, Turkey), Sevgi Altinok and Gul Surmelihindi for their help in the fieldwork organization and hard work on the field.

\section{References:}

AKSOY, E., INCEÖZ, M. \& KOÇYIĞIT, A. (2007) Lake Hazar Basin: A Negative Flower Structure on the East Anatolian Fault System (EAFS), SE Turkey. Turkish Journal of Earth Sciences, 16, $319-338$.

AMBRASEYS, N.N. (1989) Temporary seismic quiescence: SE Turkey. Geophysical Journal, 96, $311-331$.

AMBRASEYS, N.N. \& FINKEL, C.F. (1995) The Seismicity of Turkey and Adjacent Areas: A Historical Review, 1500 - 1800. Eren Yayıncılık ve Kitapcılık, Istanbul, 240 pp. 
AMBRASEYS, N. N. (1997) The little-known earthquake of 1866 and 1916 in Anatolian (Turkey). Journal of Seismology, 1, 289 - 299.

AMBRASEYS, N.N. \& JACKSON, J.A. (1998) Faulting associated with historical and recent earthquakes in the Eastern Mediterranean region. Geophysical Journal International, 133, $390-406$.

ARMIJO, R., MEYER, B., HUBERT-FERRARI, A. \& BARKA, A.A. (1999) Propagation of the North Anatolian Fault into the Northern Aegean: Timing and Kinematics. Geology, 27, 267 -270 .

ANGUS, D.A., WILSON, D.C., SANDVOL, E. \& NI J.F. (2006) Lithospheric structure of the Arabian and Eurasian collision zone in eastern Turkey from S-wave receiver functions. Geophysics Journal International, 166, 1335 - 1346.

ARPAT, E. \& SAROGLU, F. (1972) The East Anatolian Fault System; Thoughts on its development. Bulletin Mineral Research and Exploration Institute of Turkey, 78, 33 - 39.

AYDIN, A. \& NUR, A. (1982) Evolution of pull-apart basins and their scale independence. Tectonics, 1, $91-105$.

BARKA, A.A. \& KADINSKY-CADE, K. (1988) Strike-slip fault geometry in Turkey and its influence on earthquake activity. Tectonics, 7, $663-684$

BARKA, A.A. (1992) The North Anatolian Fault zone. Annales Tectonicae (Suppl.), 6, 164 195. 

BARKA, A.A. (1996) Slip distribution along the North Anatolian Fault associated with the large earthquakes of the period 1939 to 1967 . Bulletin of the Seismological Society of America, $86(5), 1238-1254$.

BARNES, P.M., SUTHERLAND, R., DAVY, B. \& DELTEIL, J. (2001) Rapid creation and destruction of sedimentary basins on mature strike-slip faults: an example from the offshore Alpine Fault, New Zealand. Journal of Structural Geology, 23, 1727 - 1739.

BOZKURT, E. (2001) Neotectonics of Turkey-a synthesis. Geodinamica Acta, 14, 3 - 30.

BOOKMAN R., BARTOV Y., ENZEL Y., \& STEIN M. (2006) The levels of late Quaternary lakes in the Dead Sea basin: Two centuries of research. New Frontiers in Dead Sea Paleoenvironmental Research. Geological Society of America, Special Paper, 401, 155 170.

ÇETIN, H., GÜNEYLI, H. \& MAYER, L. (2003) Paleoseismology of the Palu-Lake Hazar segment of the East Anatolian Fault Zone, Turkey. Tectonophysics, 374, 163 - 197.

CORMIER, M.H., SEEBER, L., MCHUGH, C.M.G., POLONIA, A., ÇAGATAY, N., EMRE, Ö., GASPERINI, L., GÖRÜR, N., BORTOLUZZI, G., BONATTI, E., RYAN, W.B.F. \& NEWMAN, K.R. (2006) North Anatolian Fault in the Gulf of Izmit (Turkey):Rapid vertical motion in response to minor bends of a nonvertical continental transform. Journal of Geophysical Research, 111, B04102, doi: 10.1029/2005JB003633.

COWGILL, E. (2007) Neotectonic evidence of active folding in NE Iraq and SE Turkey suggest the Taurus-Zagros thrust belt is underlain by locked, northeast-dipping megathrust. Geological Research Abstracts, 9, SRef-ID: 1607-7962/gra/EGU2007-A-04692. 
CUNNINGHAM, W.D. \& MANN, P. (2007) Tectonics of strike-slip restraining and releasing bends. Geological Society, London, Special Publications, 290, 239 - 253

DEWEY, J.F. \& SENGÖR, A.M.C. (1979) Aegean and surrounding regions: complex multi-plate and continuum tectonics in a convergent zone. Geological Society of America Bulletin, 90(I), $84-92$.

DEWEY, J.F., HEMPTON, M.R., KIDD, W.S.F., ŞAROĞLU, F. \& SENGÖR, A.M.C. (1986) Shortening of continental lithosphere: the neotectonics of eastern Anatolia. A young collision Zone. In: Coward, M.P. \& Ries, A.C. (eds.) Collision Tectonics. Geological Society of London, Special Publication, 19, 3 - 36.

DOOLEY, T. \& MCCLAY, K. (1997) Analog modelling of strike-slip pull-apart basins. AAPG Bulletin, 81, $804-826$.

DUNNE, L.A. \& HEMPTON, M.R. (1984) Deltaic sedimentation in the Lake Hazar pull-apart basin, south-eastern Turkey. Sedimentology, 31, 401 - 412.

ENZEL, Y., BOOKMAN (KEN-TOR), R., SHARON, D., GVIRTZMAN, H., DAYAN U., ZIV, B. \& STEIN M. (2003) Late Holocene climates of the Near East deduced from Dead Sea lake level variations and modern regional winter rainfall. Quaternary Research, 60 (no.3), $263-273$.

GUIDOBONI, E., COMASTRI A. \& TRAINA G. (1994) Catalogue of Ancient Earthquakes in the Mediterranean area up to the 10th century, 1, ING-SGA, Bologna 1994, 504 pp. 
HEMPTON, M.R. (1980) Structure and morphology of the East Anatolian Transform Fault Zone near Lake Hazar. Geological Society of America Annual Meeting, Abstracts with Programs, 12,445 .

HEMPTON, M.R. \& DEWEY, J.F. (1981) Structure and tectonics of the Lake Hazar pull-apart basin, SE Turkey. Transactions, American Geophysical Union, EOS 62, 1033.

HEMPTON, M.R. (1982) Structure of the northern margin of the Bitlis Suture Zone near Sivrice, southeastern Turkey. Ph.D. Thesis, State University of New York at Albany. pp. 383.

HEMPTON, M.R. \& DEWEY, J.F. (1983) Earthquake-induced deformational structures in young lacustrine sediments, East Anatolian Fault, southeast Turkey. Tectonophysics, 98, 7 $-14$.

HEMPTON, M.R., DUNNE, L.A. \& DEWEY, J.F. (1983) Sedimentation in an active strike-slip basin, south-eastern Turkey. Journal of Geology, 91, 401 - 412.

HEMPTON, M.R. \& DUNNE, L.A. (1984) Sedimentation in pull-apart basins: active examples in Eastern Turkey. Journal of Geology, 92, 513 - 530.

HUBERT-FERRARI, A., ARMIJO, R., KING, G.C.P., MEYER, B. \& BARKA, A.A. (2002) Morphology, displacement and slip rates along the North Anatolian Fault (Turkey) Journal of Geophysical Research, 107, 10,102910,1059.

HUBERT-FERRARI, A., KING, G., VAN DER WOERD, J., VILLA, I., ALTUNEL, E. \& ARMIJO, R. (2008) Long-Term Evolution of the North Anatolian Fault: New Constraints from its Eastern Termination. In 'Geodynamics of Collision and Collapse at the Africa- 
Arabia-Eurasia Subduction Zone'. Geological Society, Special publication. Editors: Douwe van Hinsbergen, Mike Edwards, Rob Govers.

JACKSON, J. \& MCKENZIE, D.P. (1984) Active tectonics of the Alpine-Himalayan Belt between western Turkey and Pakistan. Geophysical Journal of Royal Astronomical Society, 77, $185-264$.

JACKSON, J. \& MCKENZIE, D.P. (1988) The relationship between plate motions and seismic moment tensors, and the rates of active deformation in the Mediterranean and Middle East. Geophysical Journal of Royal Astronomical Society, 93, 45 - 73.

KEKOVALI, K., KALAFAT, D., GÜNES, Y. \& YILMAZER, M. (2003) May 1, 2003 Bingöl (Turkey) Earthquake. Kandilli Observatory and Earthquake Research Institute-Seismology Division, Bogaziçi University. (http://www.emsc-csem.org/Doc/TURKEY_bingol.pdf).

KLINGER, Y., XU, X., TAPPONNIER, P., VAN DER WOERD, J., LASSERRE, C. \& KING, G. (2005) High-Resolution Satellite Imagery Mapping of the Surface Rupture and Slip Distribution of the $\mathrm{Mw} \sim 7.8,14$ November 2001 Kokoxili Earthquake, Kunlun Fault, Northern Tibet, China. Bulletin of the Seismological Society of America, 95, 1970 - 1987.

KOÇYIĞIT, A. (1989) Suşehri basin: an active fault-wedge basin on the North Anatolian Fault Zone, Turkey. Tectonophysics, 167, 13 - 29.

KOÇYIĞIT, A., YILMAZ, A., ADAMIA, S. \& KULOSHVILI, S. (2001) Neotectonics of East Anatolian Plateau (Turkey) and Lesser Caucasus: implication for transition from thrusting to strike-slip faulting. Geodinamica Acta, 14, 177 - 195. 
KOZACI, O, DOLAN, J., FINKEL, R. \& HARTLEB, R. (2007) Late Holocene slip rate for the North Anatolian Fault, Turkey, from cosmogenic 36Cl geochronology: Implications for the constancy of fault loading and strain release rates. Geology, 35, $867-870$.

LETTIS, W., BACHHUBER, J., WITTER, R., BRANKMAN, C., RANDOLPH, C.E., BARKA, A., PAGE, W.D. \& KAYA, A. (2002) Influence of Releasing Step-Overs on Surface Fault Rupture and Fault Segmentation: Examples from the 17 August 1999 Izmit Earthquake on the North Anatolian Fault, Turkey: Bulletin of the Seismological Society of America, 92, $19-42$.

LYBERIS, N.T., YURUR, T., CHOROWICZ, J., KASAPOGLU, E. \& GUNDOGDU, N. (1992) The East Anatolian Fault: an oblique collisional belt. Tectonophysics, 204, 1 - 15.

MANN, P., HEMPTOM, M.R., BRADLEY, D.C. \& BURKE, K. (1983) Development of pullapart basins. Journal of Geology, 91, $529-554$.

MANN, P., TAYLOR, F., EDWARDS, L. \& KU, T. (1995) Actively evolving microplate formation by oblique collision and sideways motion along strike-slip faults: An example from the northeastern Caribbean plate margin. Tectonophysics, 246, 1 - 69 .

MCCLAY, K. \& BONORA, M. (2001) Analog models of restraining stepovers in strike-slip fault systems. AAPG Bulletin, 85, 233 - 260.

MCCLUSKY, S., BALASSANIAN, S., BARKA, A., DEMIR, C., ERGINTAV, S., GEORGIEV, I., GURKAN, O., HAMBURGER, M., HURST, K., KAHLE, H., KASTENS, K., KEKELIDZE, G., KING, R., KOTZEV, V., LENK, O., MAHMOUD, S., MISHIN, A., NADARIYA, M., OUZOUNIS, A., PARADISSIS, D., PETER, Y., PRILEPIN, M., REILINGER, R., SANLÝ, I., SEEGER, H., TEALEB, A., TOKSÖZ, M.N., \& VEIS, G. 
(2000) GPS constraints on plate motion and deformation in the eastern Mediterranean: Implication for plate dynamics. Journal of Geophysical Research, 105, 5695 - 5719.

MCKENZIE, D.P. (1972) Active tectonics of the Mediterranean region. Geophysical Journal of the Royal Astronomical Society, 30, 109 - 185.

MCQUARRIE, N., STOCK, J.M., VERDEL, C. \& WERNICKE, B.P. (2003) Cenozoic ecolution of neotethys and implications for the causes of plate motions. Geophysical Research Letters, 30, 2036, doi: 10.1029/2003GL017992.

MUEHLBERGER, W.B. \& GORDON, M.B. (1987) Observations on the complexity of the East Anatolian Fault, Turkey. Journal of Structural Geology, 9 (7), 899 - 903.

NALBANT, S.S., MCCLOSKEY, J., STEACY, S. \& BARKA A.A. (2002) Stress accumulation and increased seismic risk in eastern Turkey. Earth and Planetary Science Letters, 195, 291 $-298$.

ÖRGÜlÜ, G., AKTAR, M., TÜRKELli, N., SANDVOL, E. \& BARAZANGI, M. (2003) Contribution to the seismotectonics of Eastern Turkey from moderate and small size events. Geophysical Research Letters, 30, doi: 10.1029/2003GL018258.

ÖZKAN-AYGÜN, Ç. (2006) Hazar Lake Sunken City. Frankfurter elektronische Rundschau zur Altertumskunde, 2, $31-35$.

RAHE, B., FERRILL, D.A. \& MORRIS, A.P. (1998) Physical analog modelling of pull-apart basin evolution. Tectonophysics, $\mathbf{2 8 5}, 21-40$.

REILINGER, R., MCCLUSKY, S., VERNANT, P., LAWRENCE, S., ERGINTAV, S., CAKMAK, R., OZENER, H., KADIROV, F., GULIEV, I., STEPANYAN, R., 
NADARIYA, M., HAHUBIA, G., MAHMOUD, S., SAKR, K., ARRAJEHI, A., PARADISSIS, D., AL-AYDRUS, A., PRILEPIN, M., GUSEVA, T., EVREN, E., DMITROTSA, A., FILIKOV, S.V., GOMEZ, F., AL-GHAZZI R. \& KARAM G. (2006) GPS constraints on continental deformation in the Africa-Arabia-Eurasia continental collision zone and implications for the dynamics of plate interactions. Journal of Geophysical Research, 111, B05411, doi: 10.1029/2005JB004051.

ROBERTSON, A., USTAÖMER, T., PARLAK O., ÜNLÜGENÇ U.C., TAŞLI K. \& İNAN N. (2006) The Berit transect of the Tauride thrust belt, S Turkey: Late Cretaceous-Early Cenozoic accretionary/collisional processes related to closure of the Southern Neotethys. Journal of Asian Earth Sciences, 27, 108-145

ŞAROĞLU, F., EMRE, Ö. \& KUŞÇU, İ. (1992) The East Anatolian Fault zone of Turkey. Annales Tectonicae, 99 - 125 (Special Issue-Supplement to Volume VI).

ŞENGÖR, A.M.C., GÖRÜR, N. \& ŞAROĞLU, F. (1985) Strike-slip faulting and related basin formation in zones of tectonic escape: Turkey as a case study. In: Biddle, K.T. \& ChristieBlick, N. (eds) Strike-slip faulting and Basin formation. Society of Economic Paleontologists and Mineralogist, Special Publication, 227 - 267.

ŞENGÖR, A.M.C., TUYSUZ, O., IMREN, C., SAKINÇ, M., EYIDOGAN, H., GÖRÜR, N., LE PICHON, X. \& RANGIN, C. (2004) The North Anatolian Fault: A New Look. Annual Review of Earth and Planetary Sciences, 33, 37 - 112.

SYLVESTER, A.G. (1988) Strike-slip faults. Geological Society of America Bulletin, 100, 1666 $-1703$. 
TAN, O., TAPIRDAMAZ, C.M. \& YÖRÜK, A. (2008) The Earthquake Catalogues for Turkey. Turkish Journal of Earth Sciences, 17, $405-418$.

TAYMAZ, T., EYIDOGAN, H. \& JACKSON, J. (1991) Source parameters of large earthquakes in the East Anatolian Fault Zone (Turkey). Geophysical Journal International, 106, 537 550.

TEPEUĞUR, E. \& YAMAN, M. (2007) 21 Şubat 2007 Sivrice (Elaziğg) deprem raporu. Deprem Araştirma dairesi rapor, 5690 - 1. http://sismo.deprem.gov.tr/deprem/depremraporlari/2102 2007-sivrice-elazig_rpr

TONBUL S. \& YİĞİT A. (1995) Pleyistosen'den Günümüze Hazar Pleyistosen'den Günümüze Hazar Gölü'ndeki Seviye Değişmeleri ve Hatunköy Kapması. Hazar Gölü ve Çevresi Sempozyumu , $41-69$, Sivrice-ELAZIĞ.

TOSUN, H. (2007) River basin risk analysis. International Water Power and Dam Construction. http://www.waterpowermagazine.com/storyprint.asp?sc=2043704.

WELLS, D.L. \& COPPERSMITH, K.J. (1994) New Empirical Relationships among Magnitude, Rupture Length, Rupture Width, Rupture Area, and Surface Displacement. Bulletin of the Seismological Society of America, 88, $974-1002$.

WESTAWAY, R. (1994) Present-day kinematics of the Middle East and eastern Mediterranean. Journal of Geophysical Research, 99, 12071 - 12090.

WESTAWAY, R. (1995) Deformation around stepovers in strike-slip fault zones. Journal of Structural Geology, 17, 831 - 846. 
WESTAWAY, R. \& ARGER, J. (1996) The Gölbasi basin, southeastern Turkey: a complex discontinuity in a major strike-slip fault zone. Journal of the Geological Society, 153, 729 744.

WESTAWAY, R. \& ARGER, J. (2001) Kinematics of the Malatya-Ovacik Fault Zone. Geodinamica Acta, 14, 103 - 131.

WESTAWAY, R. (2003) Kinematics of the Middle East and Eastern Mediterranean Updated. Turkish Journal of Earth Sciences, 12, 5 - 56.

WICK, L., LEMCKE, G. \& STURM, M. (2003) Evidence of Lateglacial and Holocene climatic change and human impact in eastern Anatolia: high-resolution pollen, charcoal, isotopic and geochemical records from the laminated sediments of Lake Van, Turkey. The Holocene, 13, $665-675$

WILCOX, R.E., HARDING, T.P. \& SEELY, D.R. (1973) Basin wrench tectonics. AAPG Bulletin, 57, $74-96$.

WU, J.E., MCCLAY, K., WHITEHOUSE, P. \& DOOLEY, T. (2009) 4D analogue modelling of transtensional pull-apart basins. Marine and Petroleum Geology, 26, 1608 - 1623.

ZHANG, P.Z., BURCHFIEL, B.C., CHEN, S. \& DENG, Q. (1989) Extinction of pull-apart basins. Geology, 17, $814-817$. 


\section{FIGURE CAPTION}

Fig. 1: Tectonic map of the East Anatolian Fault zone (north-eastern part). Isoseismals VII and VI of the March 27, 1874 earthquake are indicated (Ambraseys, 1989). Dams, main rivers and cities are shown. The arrows indicate relative fault motions. Inset: schematic diagram of the continental extrusion of the Anatolian block away from the Arabia-Eurasia collision zone including GPS vectors relative to Eurasia (McClusky et al., 2000; Reilinger et at., 2006). NAFZ: North Anatolian Fault Zone; EAFZ: East Anatolian Fault Zone; DSFZ: Dead Sea Fault Zone; MF: Malatya Fault; SF: Sürgü Fault; HSZ: Hellenic Subduction Zone; KTJ: Karliova Triple Junction; TTJ: Türkoglu Triple Junction. Projections: Lat/Long-WGS84.

Fig. 2: Central part of the East Anatolian Fault (EAF) showing fault segmentation according to Şaroğlu et al. (1992) and Çetin et al. (2003). Focal mechanism solutions of 20 recent earthquakes are indicated with the date of occurrence in brackets below them. Ms: Surface-wave Magnitude; Mw: Moment Magnitude; Md: Duration Magnitude; Mb: Body Magnitude. Focal mechanism 1 is taken from Taymaz et al. (1991), focal mechanism 2 from Jackson \& McKenzie (1984); focal mechanisms 3, 4, 5, 6, 7, 8, 9, 10, 11, 12, 13 and 14 from Örgülü et al. (2003), focal mechanism 15 from Tan et al. (2008), focal mechanism 16 from the Global CMT Catalogue and focal mechanisms 18, 19 and 20 from Tepeuğur \& Yaman (2007). Projections: UTM-WGS 84, 37N.

Fig. 3: Onland fault map of the Hazar Basin area plotted on SPOT image showing the seismic survey grid and side-scan sonar path of the 2007 geophysical campaign. Orange dot indicates the position of the test-pit dug on the eastern alluvial fan during the same campaign. Red dots show the location of the palaeo-seismic trenches and exposures studied by Çetin et al. (2003). HF: 


\author{
Havri Fault; GF: Gezin Fault; AF: Aidin Fault; NwF: North-western Fault; SwF: South-western \\ Fault. Projections: UTM-WGS 84, 37N.
}

Fig. 4: Bathymetry and fault map of Lake Hazar obtained from the seismic survey. The position of the images plotted in Fig. 5 (labelled Fig. 5) and seismic profiles shown in Fig. 6 (P17, P40, P22, P34, P04 and P29) are indicated. The uplifted outlet of Lake Hazar during the 1874 and 1875 earthquakes (Ambraseys, 1989) is marked by a red circle. MF: Master Fault; NF: Northern Fault; SF: Southern Fault; NwS: Northwestern Splay; DB: Deep Basin; FB: Flat Basin; SeB: small-elongated basin; Pr: promontory; Pl: plateau; KA: Kilise Adasi Island. Projections: UTMWGS 84, 37N.

Fig. 5: Images obtained from the side-scan sonar survey (See Fig. 4 for location). Fault scarps are marked by green lines. a) The small-elongated basin bounded to the north and south by two splays of the Master Fault (MF), the Mfa' and Mfa. b) Northern Fault (NF) and western portion of the small-elongated basin.

Fig. 6: Seismic profiles (See Fig. 4 for location) not interpreted (above) and interpreted (below). a) Profile 17, b) profile 40, c) profile 22, d) profile 34 , e) profile 4 and f) profile 29. Black lines represent the main faults, which apparent motions are indicated by black arrows. SF: Southern Fault; MF: Master strike-slip Fault; NF: Northern Fault. Mfa, Mfa' and Mfb: main strands of the MF; NwS: Northwestern Splay; LS: probable lowstand indicator. The y-axis indicates the depth in Two Way Travel Time (TWTT) expressed in seconds, whereas the x-axis represents the horizontal distant along the profile in metres. Vertical exaggeration $\sim 8$ 
Fig. 7: Details of seismic profile 4 showing probable lowstand indicators. Seismic horizon 1 (H1) is indicated marking the probable base of the Holocene sequence. The asterisk represents the location of one of the $5.5 \mathrm{~m}$ core collected at this area. Vertical exaggeration $\sim 9$.

Fig. 8: Map showing the stream system around Lake Hazar and, within the lake, the thickness of the Holocene sedimentary unit in swaths along the seismic lines. Black lines: main faults; red line: outlet of Lake Hazar; green-dash line: catchment of the basin.

Fig. 9: Isopach maps obtained from horizons $\mathrm{H} 3$ and $\mathrm{H} 1$ (a), H5 and H3 (b) and H9 and H5 (c) plotted with the structural map of Lake Hazar. The apparent migration of the depocentre throughout time is indicated (black arrow in Fig. 9c). Black asterisk: position of the depocentre in isopach map H3 - H1; magenta asterisk: depocentre location in isopach map H5 - H3; pink asterisk: probable position of the depocentre in isopach map H9 - H5.

Fig. 10: Seismic line 38 (see Fig. 4 for location) showing different phases of deformation of the southern sub-basin bounded to the south by the Southern Fault (SF) and to the north by the Master Fault (MF). Main structural change occurs above H5: below H5 the sedimentary infill is greater near the SF and decreases toward the MF, where horizons are dragged downward. Above H5 the sedimentary infill is thinner near the SF and increases slightly toward the MF where horizons are dragged upward.

Fig. 11: Isopach map between the lake floor and the base of the lacustrine infill plotted with the structural map of Lake Hazar (black lines). An estimation of the apparent total offset of the Deep Basin along the Master Fault is indicated. 
Fig. 1: Tectonic map of the East Anatolian Fault zone (north-eastern part). Isoseismals VII and VI of the March 27, 1874 earthquake are indicated (Ambraseys, 1989). Dams, main rivers and cities are shown. The arrows indicate relative fault motions. Inset: schematic diagram of the continental extrusion of the Anatolian block away from the Arabia-Eurasia collision zone including GPS vectors relative to Eurasia (McClusky et al., 2000; Reilinger et at., 2006). NAFZ: North Anatolian Fault Zone; EAFZ: East Anatolian Fault Zone; DSFZ: Dead Sea Fault Zone; MF: Malatya Fault; SF: Sürgü Fault; HSZ: Hellenic Subduction Zone; KTJ: Karliova Triple Junction; TTJ: Türkoglu Triple Junction. Projections: Lat/Long-WGS84. 


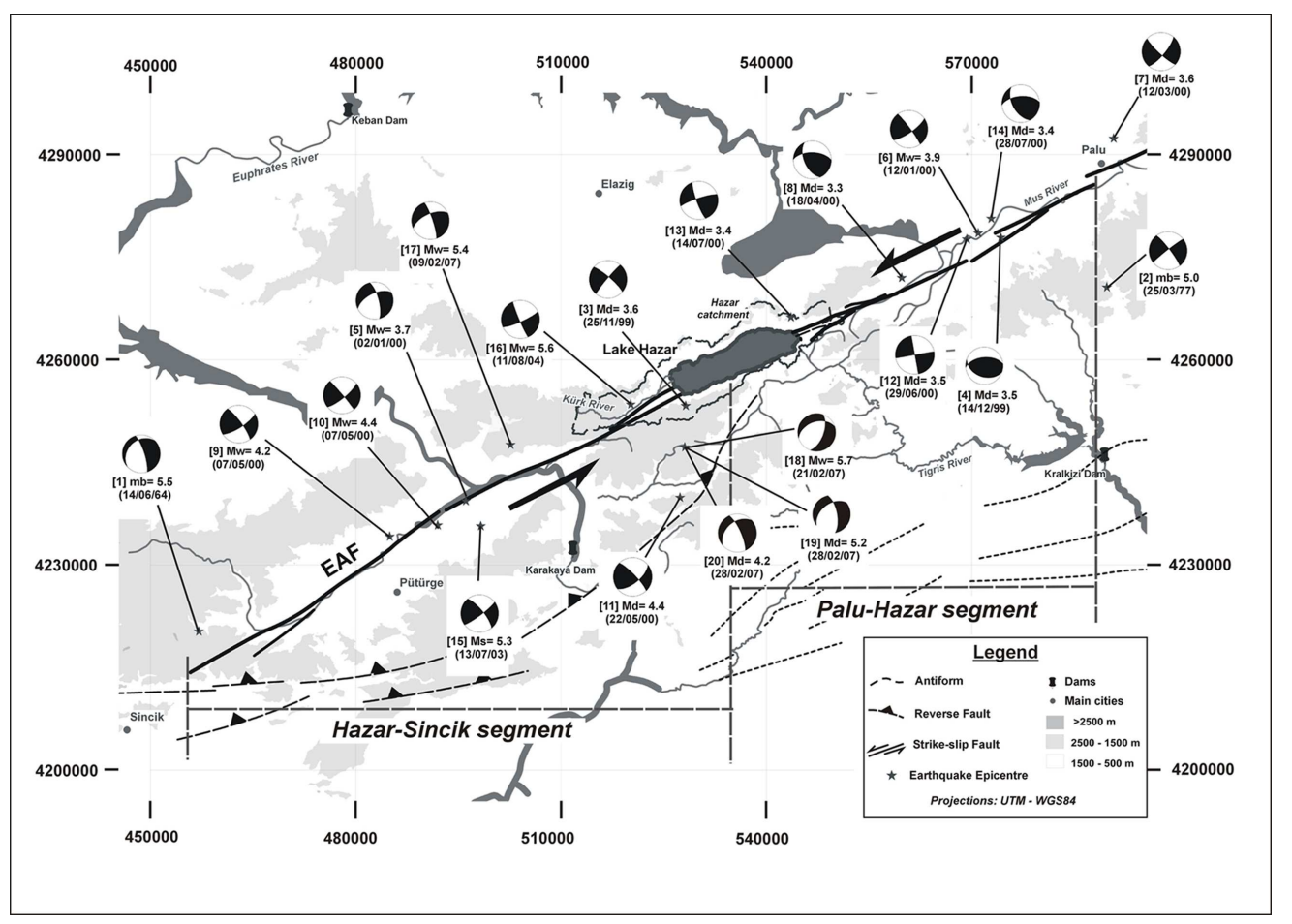

Fig. 2: Central part of the East Anatolian Fault (EAF) showing fault segmentation according to Şaroğlu et al. (1992) and Çetin et al. (2003). Focal mechanism solutions of 20 recent earthquakes are indicated with the date of occurrence in brackets below them. Ms: Surface-wave Magnitude; Mw: Moment Magnitude; Md: Duration Magnitude; Mb: Body Magnitude. Focal mechanism 1 is taken from Taymaz et al. (1991), focal mechanism 2 from Jackson \& McKenzie (1984); focal mechanisms 3, 4, 5, 6, 7, 8, 9, 10, 11, 12, 13 and 14 from Örgülü et al. (2003), focal mechanism 15 from Tan et al. (2008), focal mechanism 16 from the Global CMT Catalogue and focal mechanisms 18, 19 and 20 from Tepeuğur \& Yaman (2007). Projections: UTM-WGS 84, 37N. $167 \times 119 \mathrm{~mm}(400 \times 400 \mathrm{DPI})$ 


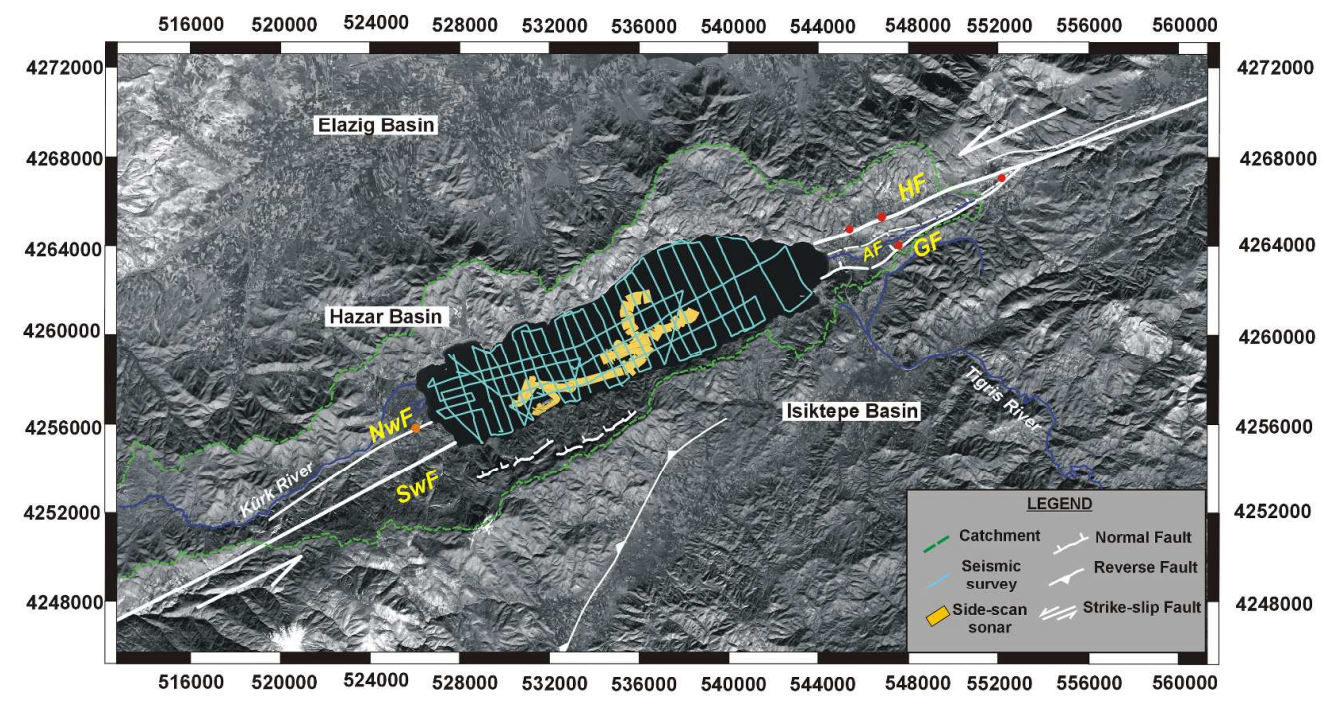

Fig. 3: Onland fault map of the Hazar Basin area plotted on SPOT image showing the seismic survey grid and side-scan sonar path of the 2007 geophysical campaign. Orange dot indicates the position of the test-pit dug on the eastern alluvial fan during the same campaign. Red dots show the location of the palaeo-seismic trenches and exposures studied by Çetin et al. (2003). HF: Havri Fault; GF: Gezin Fault; AF: Aidin Fault; NwF: North-western Fault; SwF: South-western Fault. Projections: UTM-WGS 84, 37N. 


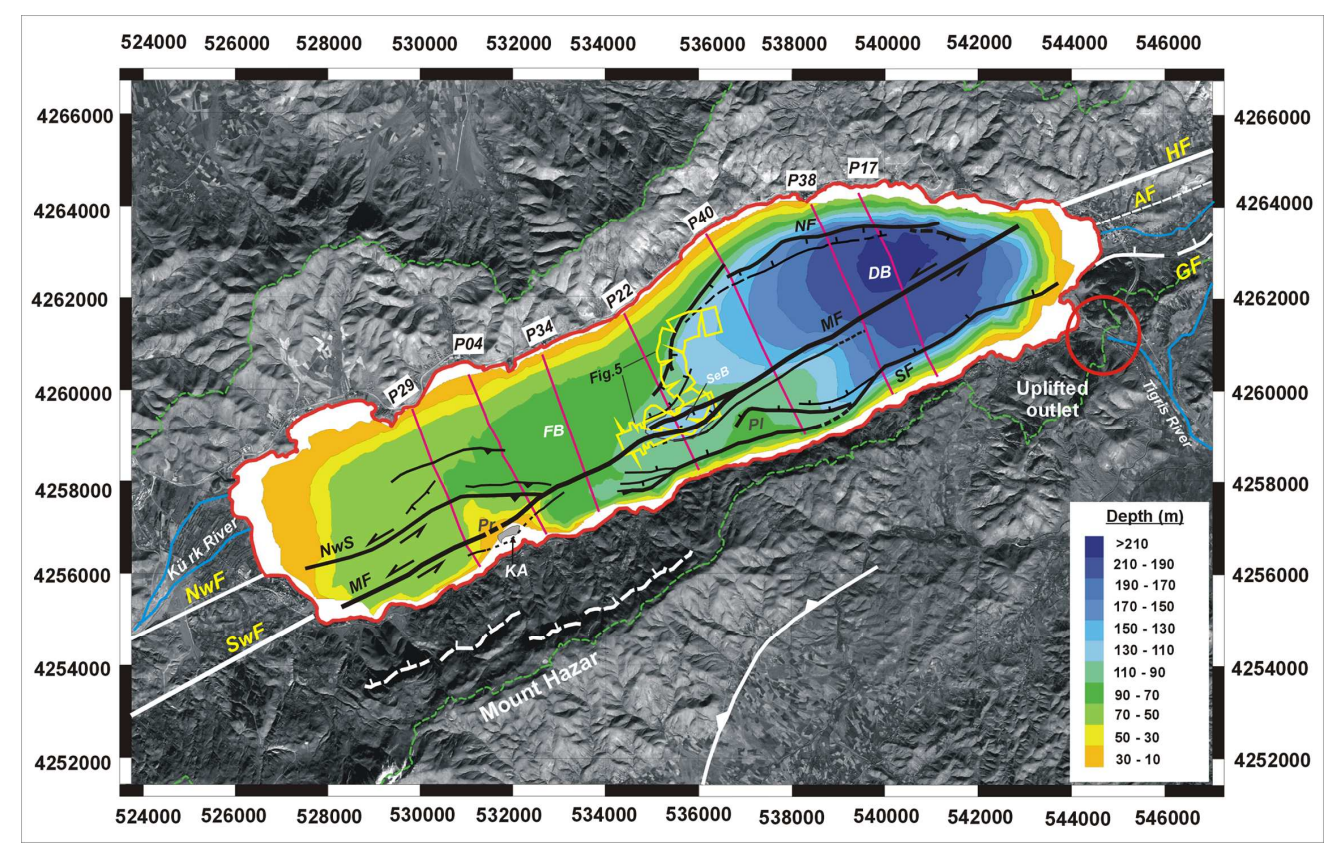

Fig. 4: Bathymetry and fault map of Lake Hazar obtained from the seismic survey. The position of the images plotted in Fig. 5 (labelled Fig. 5) and seismic profiles shown in Fig. 6 (P17, P40, P22, P34, P04 and P29) are indicated. The uplifted outlet of Lake Hazar during the 1874 and 1875 earthquakes (Ambraseys, 1989) is marked by a red circle. MF: Master Fault; NF: Northern Fault; SF: Southern Fault; NwS: Northwestern Splay; DB: Deep Basin; FB: Flat Basin; SeB: smallelongated basin; Pr: promontory; PI: plateau; KA: Kilise Adasi Island. Projections: UTM-WGS 84, $37 \mathrm{~N}$. 


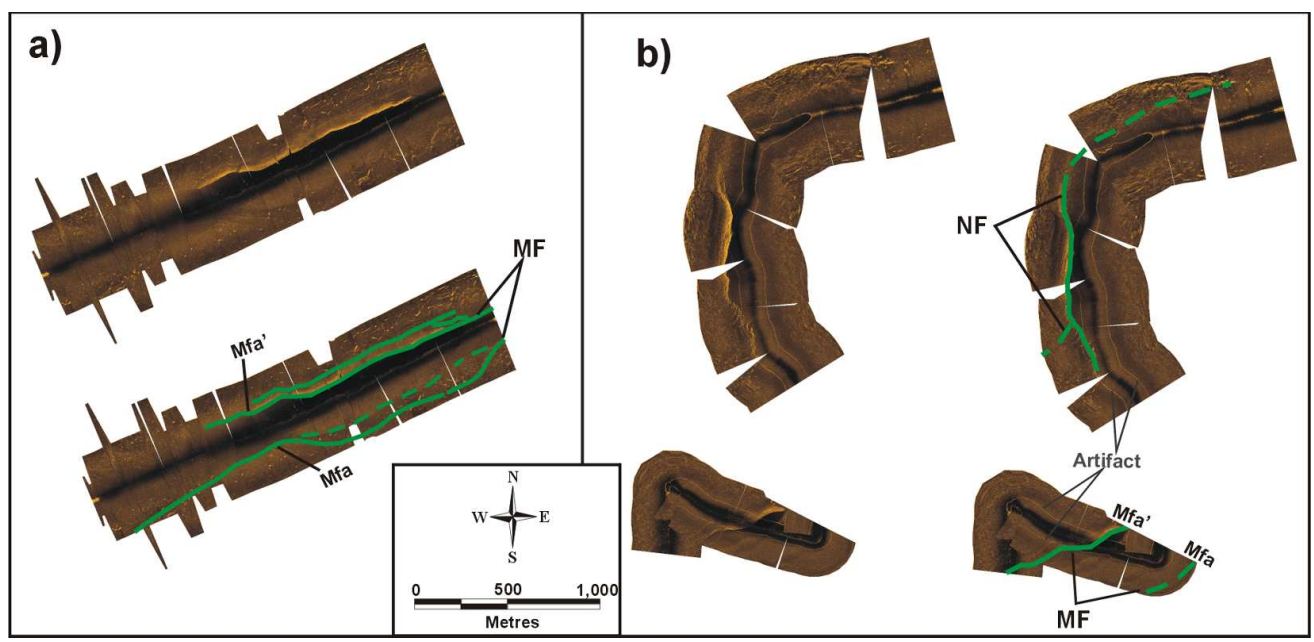

Fig. 5: Images obtained from the side-scan sonar survey (See Fig. 4 for location). Fault scarps are marked by green lines. a) The small-elongated basin bounded to the north and south by two splays of the Master Fault (MF), the Mfa' and Mfa. b) Northern Fault (NF) and western portion of the smallelongated basin. 
Fig. 6: Seismic profiles (See Fig. 4 for location) not interpreted (above) and interpreted (below). a) Profile 17, b) profile 40, c) profile 22, d) profile 34, e) profile 4 and f) profile 29 . Black lines represent the main faults, which apparent motions are indicated by black arrows. SF: Southern Fault; MF: Master strike-slip Fault; NF: Northern Fault. Mfa, Mfa' and Mfb: main strands of the MF; NwS: Northwestern Splay; LS: probable lowstand indicator. The y-axis indicates the depth in Two Way Travel Time (TWTT) expressed in seconds, whereas the $x$-axis represents the horizontal distant along the profile in metres. Vertical exaggeration $\sim 8$

Lake-floor

Horizon 1

Horizon 2

Horizon 3

Horizon 4

Horizon 5

Horizon 6

Horizon 7

\section{Horizon 8}

Horizon 9

Horizon 10

Horizon 11

Horizon 12

Base of the infill

Multiple 

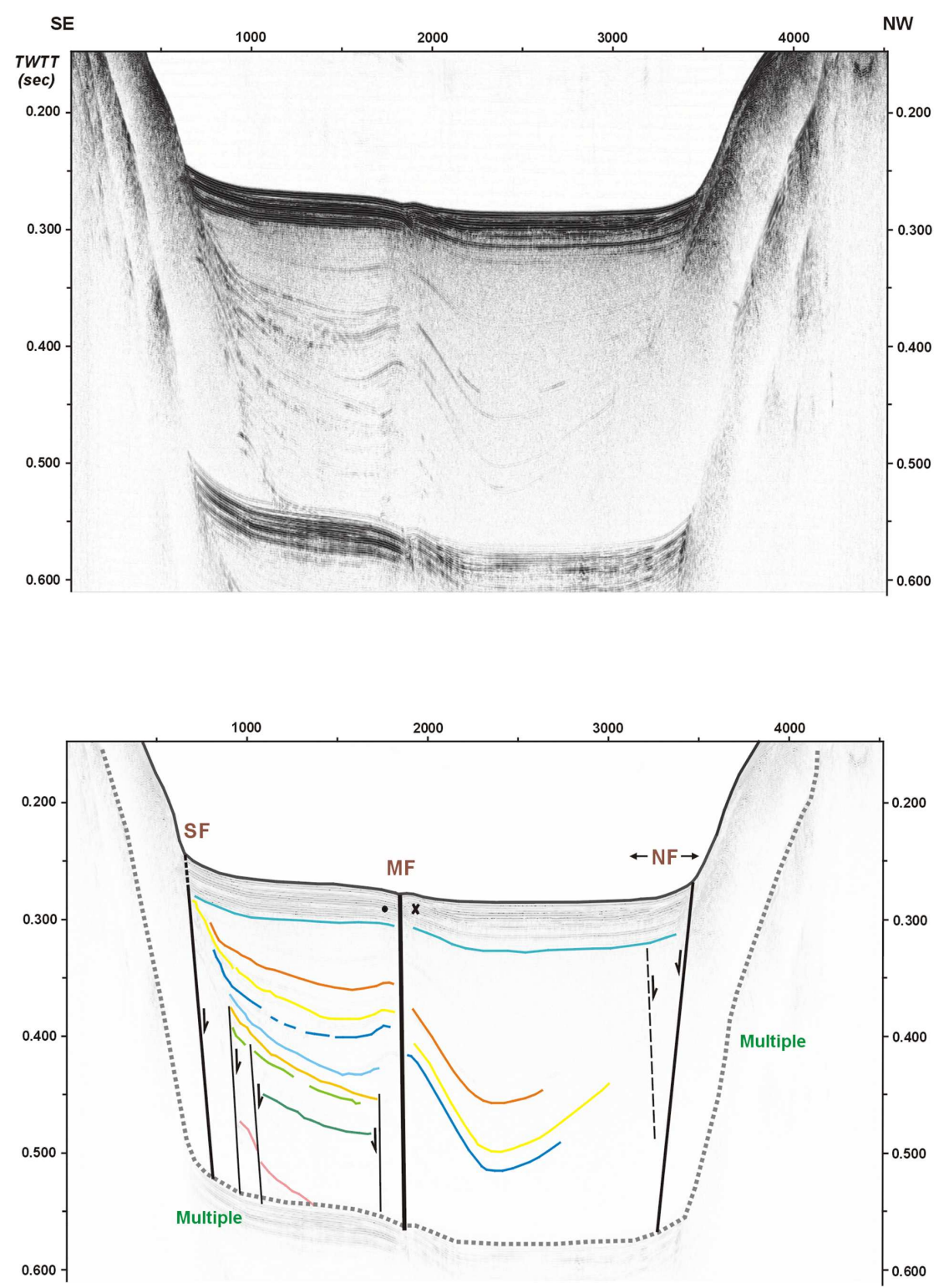

Fig. $6 a$ 

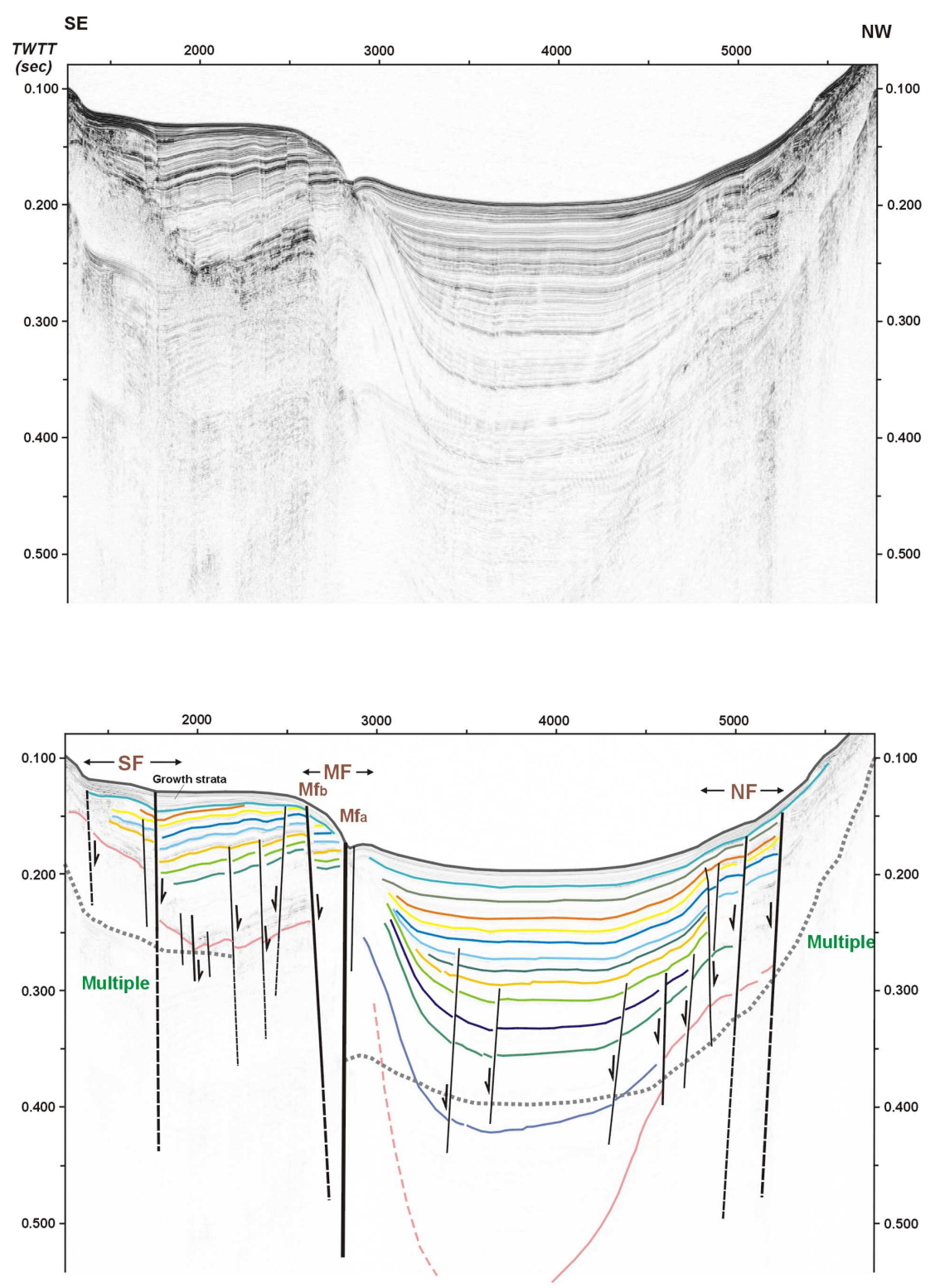

Fig. 6b 

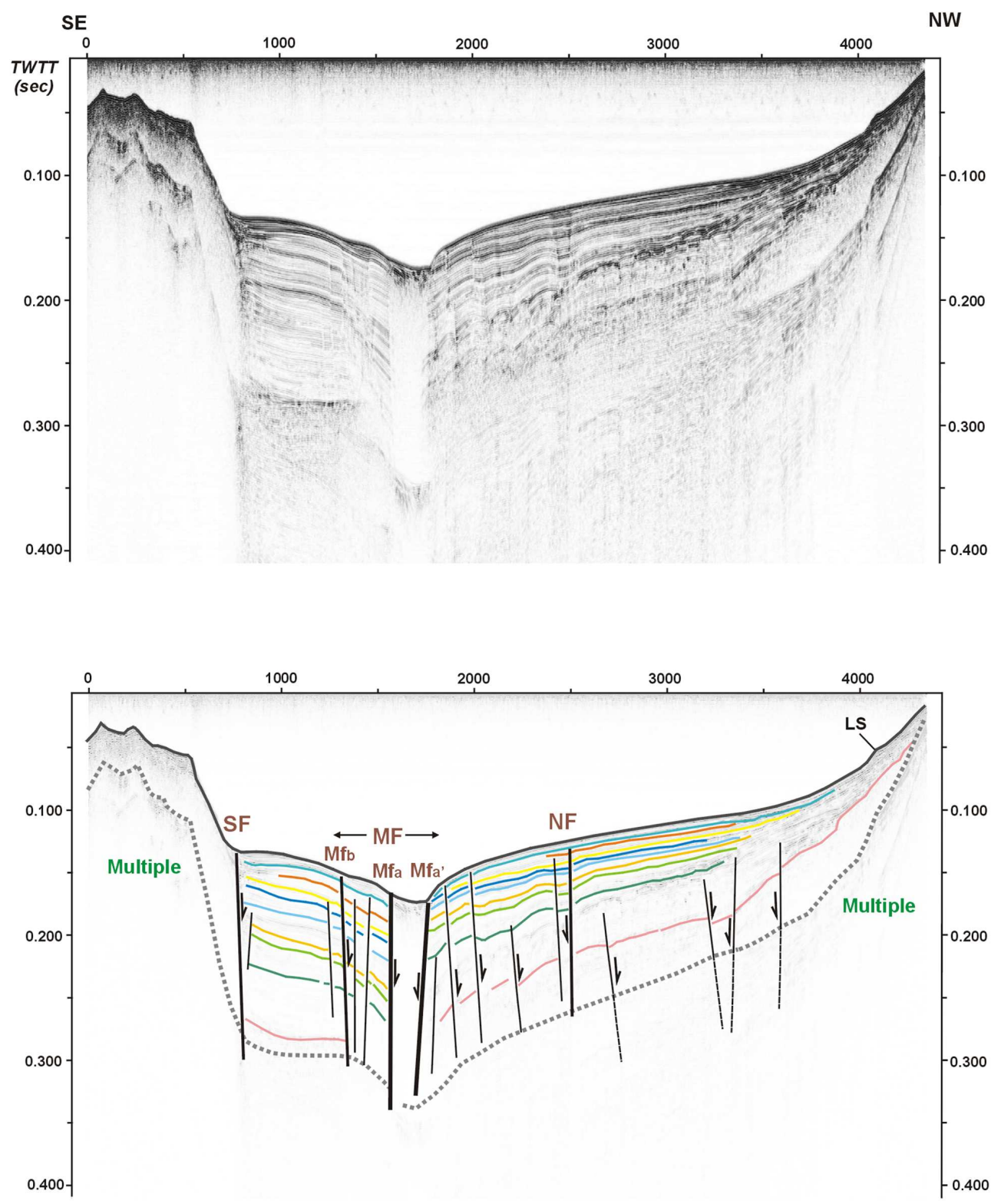

Fig. 6c 

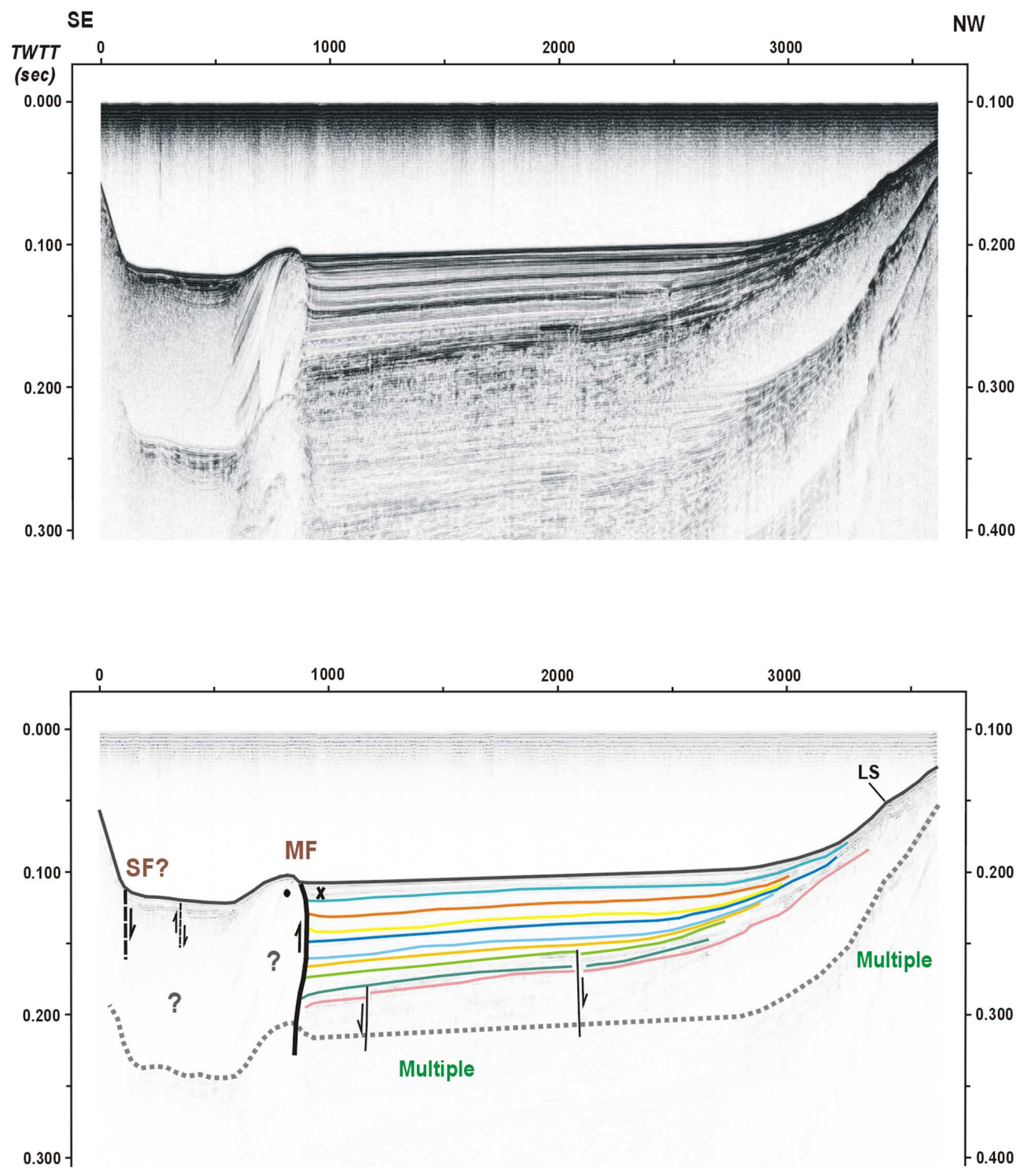

Fig. 6d 


\section{Page 51 of 57}
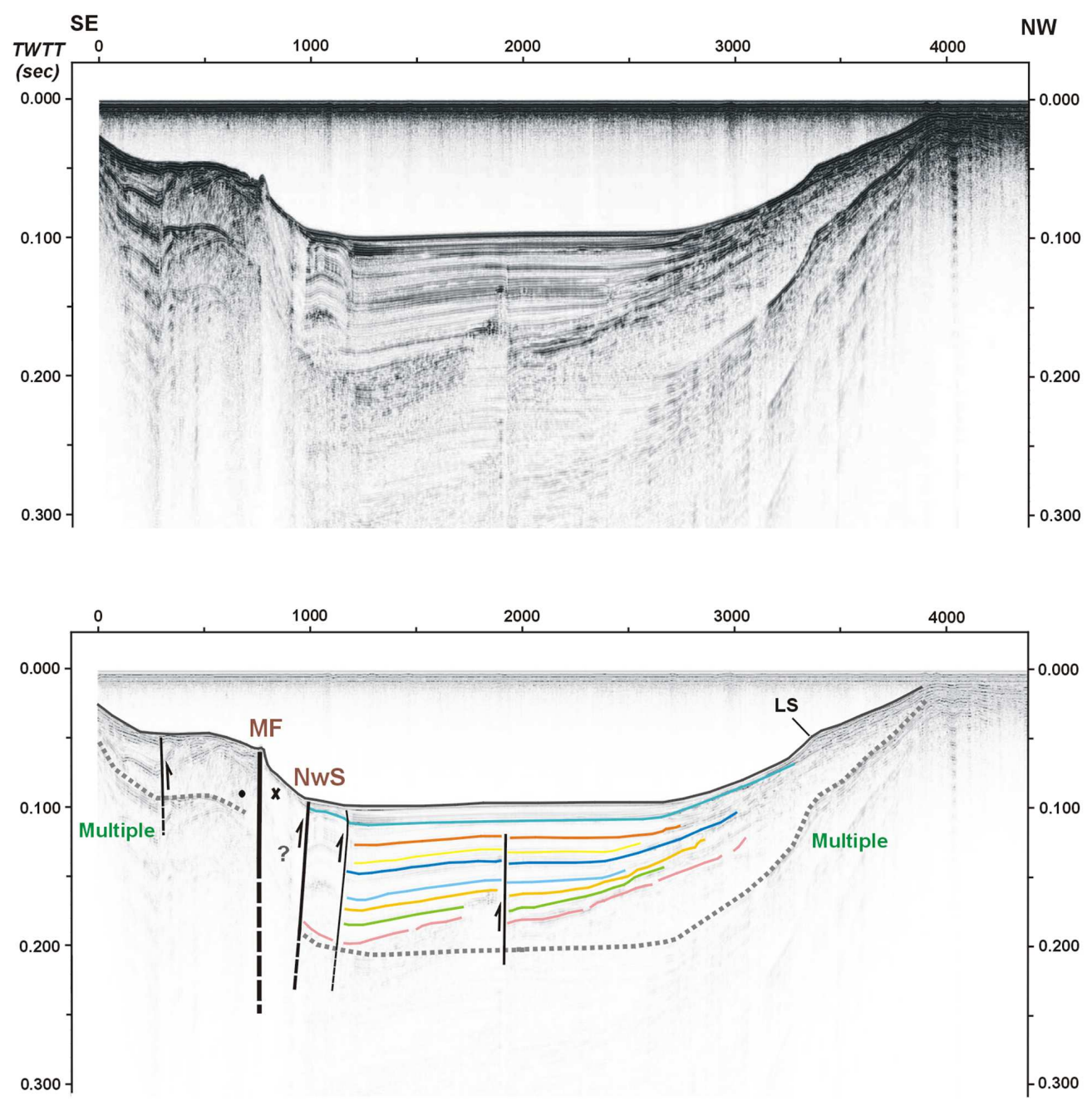

Fig. 6e 

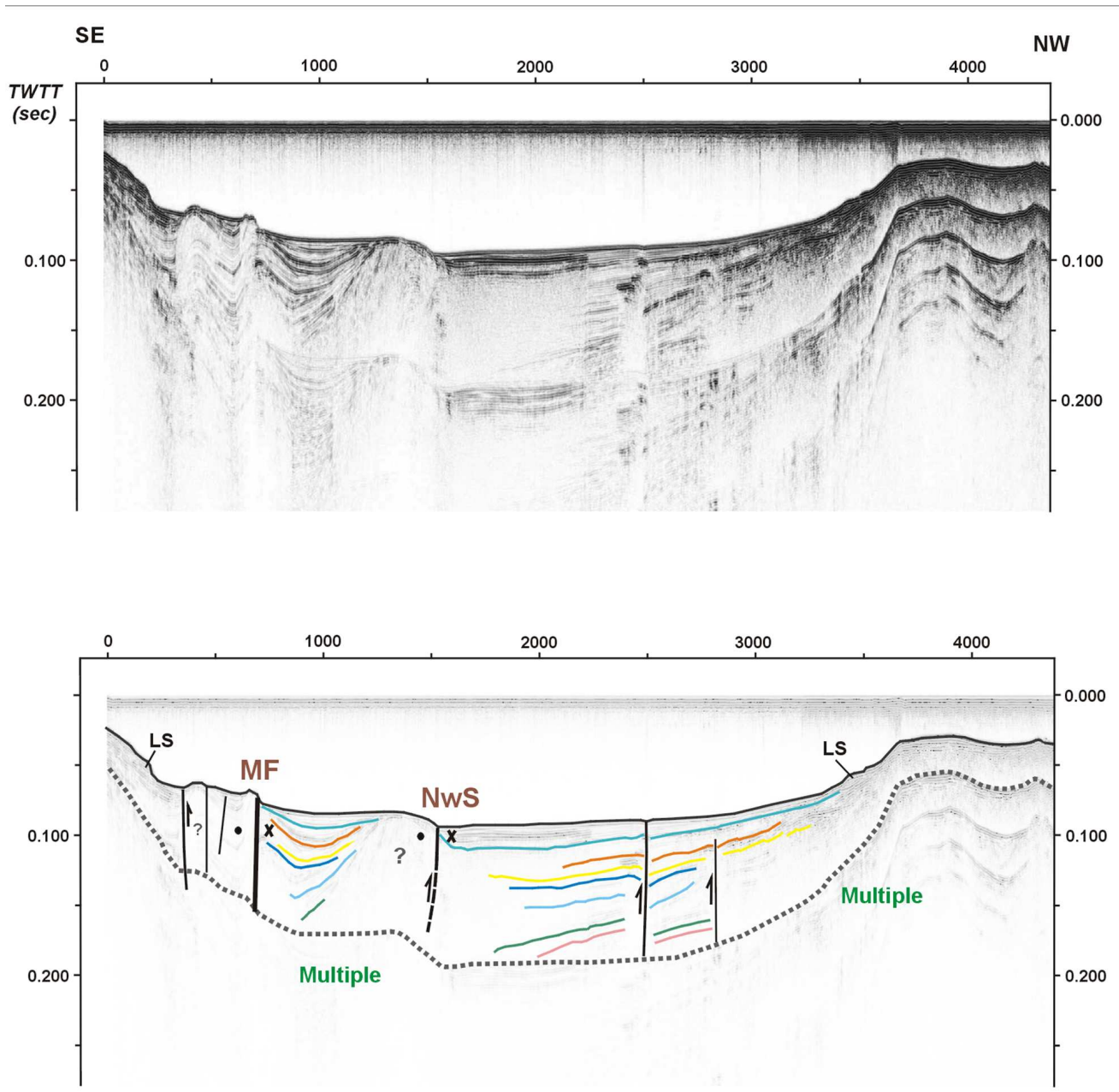

Fig. $6 f$ 


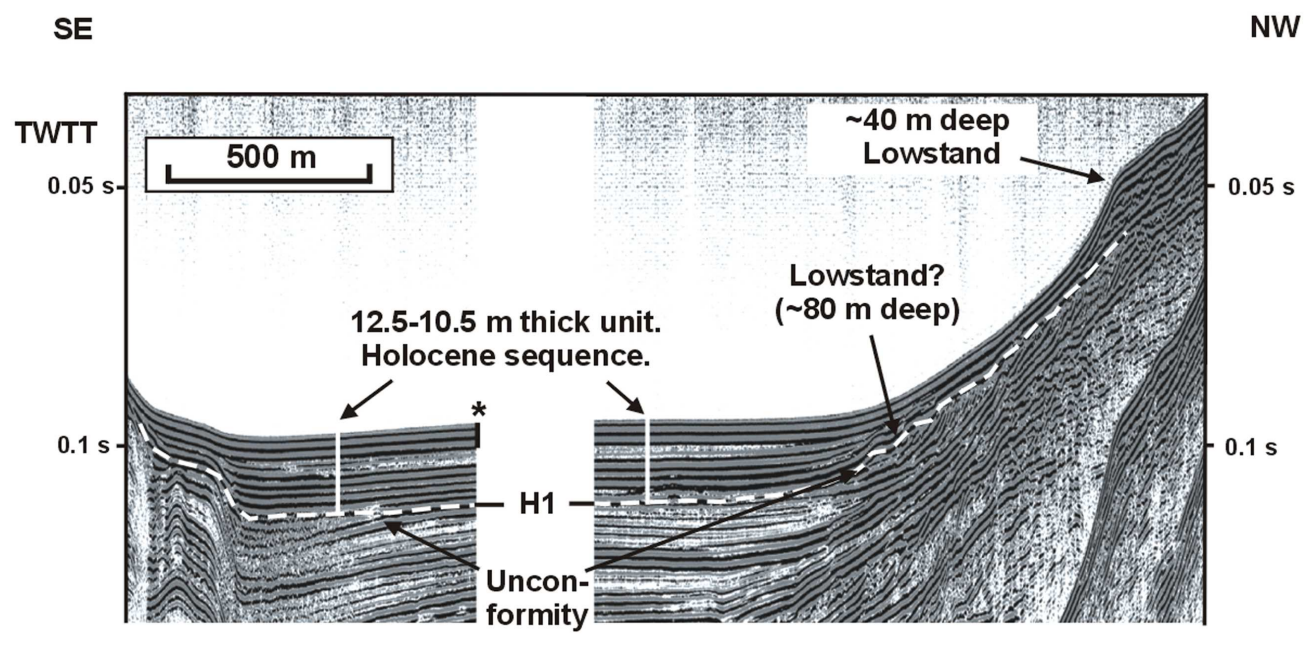

Fig. 7: Details of seismic profile 4 showing probable lowstand indicators. Seismic horizon $1(\mathrm{H} 1)$ is indicated marking the probable base of the Holocene sequence. The asterisk represents the location of one of the $5.5 \mathrm{~m}$ core collected at this area. Vertical exaggeration $\sim 9$. 
Fig. 8: Map showing the stream system around Lake Hazar and, within the lake, the thickness of the Holocene sedimentary unit in swaths along the seismic lines. Black lines: main faults; red line: outlet of Lake Hazar; green-dash line: catchment of the basin. 


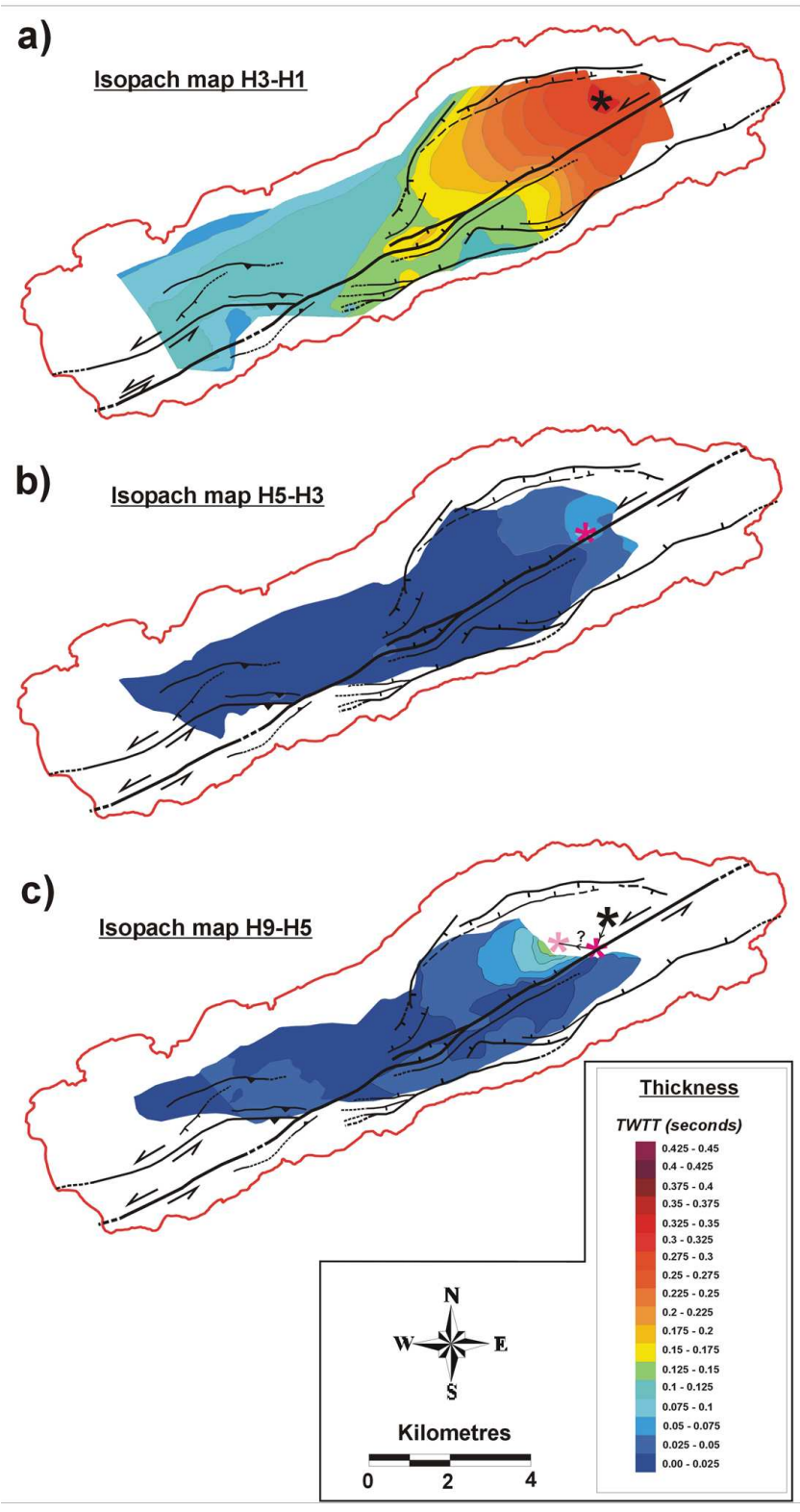

Fig. 9: Isopach maps obtained from horizons $\mathrm{H} 3$ and $\mathrm{H} 1$ (a), $\mathrm{H} 5$ and $\mathrm{H} 3$ (b) and $\mathrm{H} 9$ and $\mathrm{H} 5$ (c) plotted with the structural map of Lake Hazar. The apparent migration of the depocentre throughout time is indicated (black arrow in Fig. 9c). Black asterisk: position of the depocentre in isopach map $\mathrm{H} 3-\mathrm{H} 1$; magenta asterisk: depocentre location in isopach map H5 - H3; pink asterisk: probable position of the depocentre in isopach map $\mathrm{H} 9-\mathrm{H} 5$. 


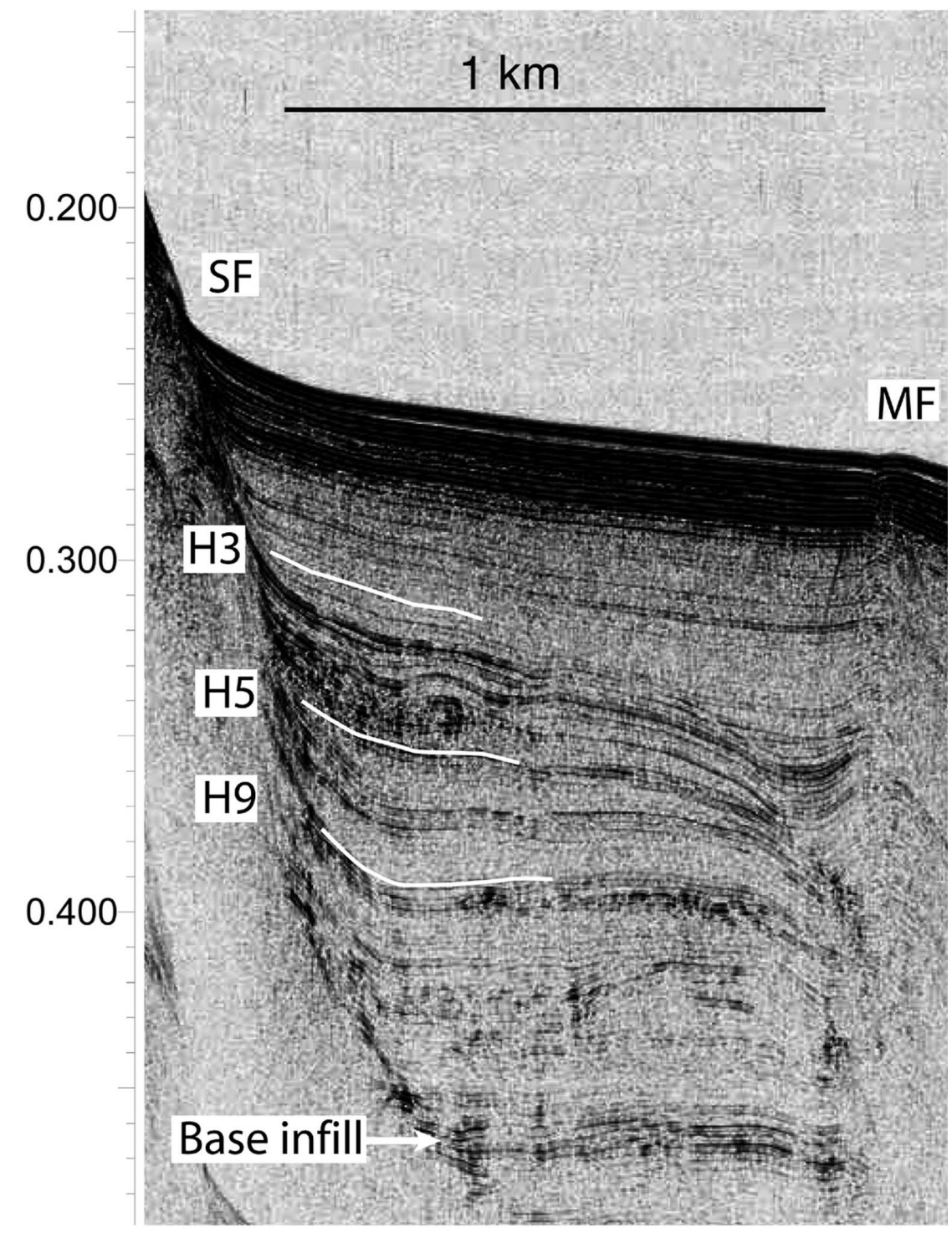

(s) twt

Fig. 10: Seismic line 38 (see Fig. 4 for location) showing different phases of deformation of the southern sub-basin bounded to the south by the Southern Fault (SF) and to the north by the Master Fault (MF). Main structural change occurs above H5: below H5 the sedimentary infill is greater near the SF and decreases toward the MF, where horizons are dragged downward. Above H5 the sedimentary infill is thinner near the SF and increases slightly toward the MF where horizons are dragged upward. $80 \times 110 \mathrm{~mm}(500 \times 500$ DPI $)$ 
Fig. 11: Isopach map between the lake floor and the base of the lacustrine infill plotted with the structural map of Lake Hazar (black lines). An estimation of the apparent total offset of the Deep Basin along the Master Fault is indicated. 